\title{
Review \\ Gender Differences in Urothelial Bladder Cancer: Effects of Natural Killer Lymphocyte Immunity
}

\author{
Charles T. Lutz ${ }^{1,2,3, *,+}$, Lydia Livas ${ }^{1,+}$, Steven R. Presnell ${ }^{1,+}$, Morgan Sexton ${ }^{1}$ and Peng Wang ${ }^{3,4}$ \\ 1 Department of Pathology and Laboratory Medicine, University of Kentucky, Lexington, KY 40536, USA; \\ lydia.livas@unchealth.unc.edu (L.L.); Steven.Presnell@uky.edu (S.R.P.); \\ morgan.t.sexton@Vanderbilt.Edu (M.S.) \\ 2 Department of Microbiology, Immunology, and Molecular Genetics, University of Kentucky, \\ Lexington, KY 40536, USA \\ 3 Markey Cancer Center, University of Kentucky, Lexington, KY 40536, USA; p.wang@uky.edu \\ 4 Department of Internal Medicine, University of Kentucky, Lexington, KY 40536, USA \\ * Correspondence: ctlutz2@uky.edu \\ + These authors contributed equally to this work.
}

check for updates

Citation: Lutz, C.T.; Livas, L.; Presnell, S.R.; Sexton, M.; Wang, P. Gender Differences in Urothelial Bladder Cancer: Effects of Natural Killer Lymphocyte Immunity. J. Clin. Med. 2021, 10, 5163. https://doi.org/ $10.3390 /$ jcm 10215163

Academic Editor: Javier C. Angulo

Received: 10 September 2021

Accepted: 29 October 2021

Published: 4 November 2021

Publisher's Note: MDPI stays neutral with regard to jurisdictional claims in published maps and institutional affiliations.

Copyright: (c) 2021 by the authors. Licensee MDPI, Basel, Switzerland. This article is an open access article distributed under the terms and conditions of the Creative Commons Attribution (CC BY) license (https:/ / creativecommons.org/licenses/by/ $4.0 /)$.

\begin{abstract}
Men are more likely to develop cancer than women. In fact, male predominance is one of the most consistent cancer epidemiology findings. Additionally, men have a poorer prognosis and an increased risk of secondary malignancies compared to women. These differences have been investigated in order to better understand cancer and to better treat both men and women. In this review, we discuss factors that may cause this gender difference, focusing on urothelial bladder cancer (UBC) pathogenesis. We consider physiological factors that may cause higher male cancer rates, including differences in $\mathrm{X}$ chromosome gene expression. We discuss how androgens may promote bladder cancer development directly by stimulating bladder urothelium and indirectly by suppressing immunity. We are particularly interested in the role of natural killer (NK) cells in anti-cancer immunity.
\end{abstract}

Keywords: urothelial bladder cancer; natural killer cells; androgens; immunosuppression; X chromosome; sex factors

\section{Introduction}

The Gender Divide: “Instead of Ignoring Our Differences, We Need to Accept and Transcend Them." Sheryl Sandberg [1].

UBC is common, with a $2.4 \%$ lifetime risk [2]. UBC is much more common in men: out of the estimated 83,750 new UBC cases in America in 2021, about 64,280 are in men and 19,450 are in women [3]. UBC also kills more men than women: in 2021 it is estimated to kill 12,260 men and 4940 women [3]. Even when controlling for increased male exposure to carcinogens, such as tobacco and industrial chemicals, men are at an increased risk [4]. Gender differences in cancer outcomes can be due to biological or social factors. For example, well-known variances in occupation, workplace exposures, and social networks could all influence cancer incidence and survival, but not be directly due to biological sex. Furthermore, physicians sometimes treat male and female patients differently. In this review, we focus on biological sex differences that may affect UBC incidence and mortality. As we discuss below, observed UBC gender differences could be related to how androgens and the androgen receptor (AR) affect UBC development and progression. UBC gender disparity also could result if androgens suppress anti-cancer immunity. Moreover, greater transcription of some $\mathrm{X}$ chromosome genes may protect females from UBC.

Most UBC cases are identified early and are transurethrally resected. Adjuvant treatment often includes intravesicular infusion of cytotoxic chemotherapy or of bacillus Calmette-Guerin (BCG) immunotherapy. While non-muscle-invasive bladder cancer 
(NMIBC) tumors often respond to these treatments, UBC has a lifetime recurrence risk of up to $50 \%$ and requires long-term monitoring [5,6]. As a result, UBC treatment and monitoring cost more than for any other cancer [7,8]. It should be emphasized that UBC 5-year mortality rates have remained fairly consistent over the last three decades, despite advancements in treatment [2]. To help current and future patients, we must further study UBC pathogenesis. This review focuses on proposed biological reasons for high male incidence, which leads to more male deaths. What we learn from gender differences may allow us to better understand and treat UBC in both sexes.

\section{The Androgen Receptor in Bladder Cancer}

Encoded on the $\mathrm{X}$ chromosome, the androgen receptor (AR) binds to testosterone and related hormones. Testosterone stimulates cells through multiple mechanisms (Figure 1). In the classical mechanism [9], the hormone passively diffuses into the cell and binds cytoplasmic AR. Increasing potency, testosterone is reduced by 5 - $\alpha$ reductases in the cytoplasm to dihydrotestosterone (DHT), which binds to AR with high affinity. Hormone binding changes AR conformation, which allows hormone-AR complexes to enter the nucleus and either enhance or depress transcription of multiple genes [9]. In addition, AR interacts with important cytoplasmic signaling molecules, including PI3K, Src, and Ras, to initiate MAP kinase signaling [10]. In another non-classical mechanism, ZIP9 (SLC29A9) was identified as a non-AR cell surface androgen receptor (Figure 1). Upon testosterone binding, ZIP9 increased intracellular zinc and imparted an apoptotic signal [11,12]. A putative T-lymphocyte surface androgen receptor [13-15] may, in retrospect, have been ZIP9. Finally, IL-6 and IL-8 inflammatory cytokines activate AR signaling in the absence of androgens (Figure 1), via ERK, Src, FAK, and STAT3 [16,17]. AR is widely expressed in both sexes, despite large differences in androgen levels. Both sexes express AR in the bladder, including urothelium, muscularis propria (detrusor muscle), and bladder neurons [18-20]. In castrated male rats, androgen replacement therapy significantly improved urothelial thickness and muscle fiber quantity, indicating an androgen effect on these structures [21].

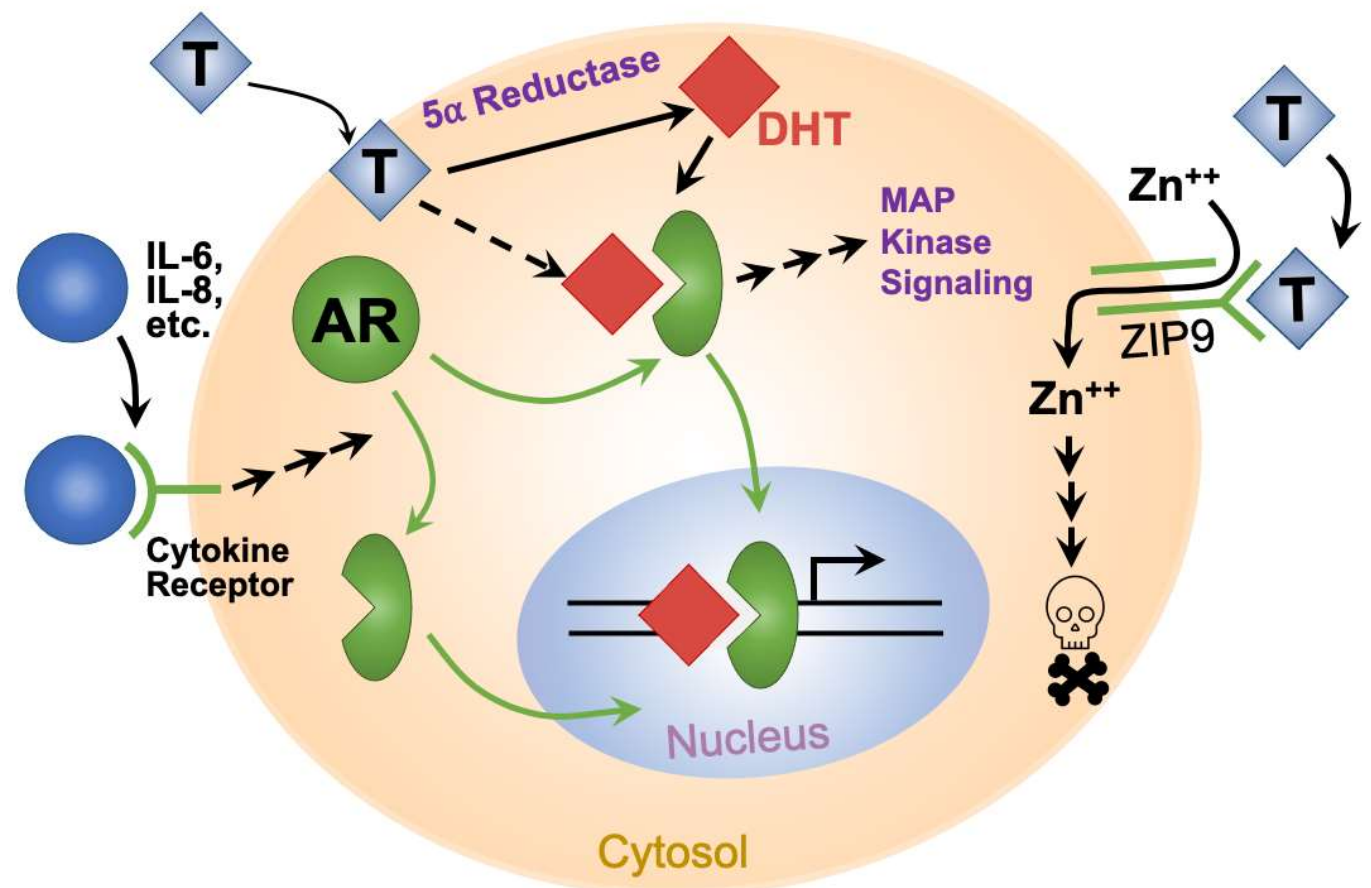

Figure 1. Schematic representation of androgen and AR signaling mechanisms in cells.

High overall male cancer risk naturally suggests that AR and testosterone accelerate cancer initiation, progression, or metastasis. For prostate cancer (PCa), this relationship is well established [22-24]. In addition to PCa, many cancers are influenced by androgens. 
For example, castration of male rats reduced both chemically induced pancreatic tumor burden and renal cell carcinoma; testosterone administration at least partly reversed this effect [25]. However, particularly aggressive cancers often do not respond to androgen deprivation therapy (ADT). Castration-resistant PCa is a classic example. It most often arises after ADT, which selects for highly aggressive castration-resistant cancer cells that proliferate, have stem cell-like properties, and survive chemotherapy [26]. Recent work has suggested a mechanism by which this may occur-Schroeder et al. [27] found that in mice, the AR antagonist, flutamide, caused PCa cells to convert to a cancer stem cell (CSC) phenotype. The process was mediated through STAT3 signaling induced by IL-6 [27,28]. As noted above, STAT3 stimulates AR in an androgen-independent mechanism [17]. Blocking mouse IL-6 mice significantly reduced PCa stem cell numbers [27].

As a general principle, hormone-resistant cancers may arise from hormone-sensitive tissue. Breast cancers often are treated with tamoxifen, a selective estrogen receptor modulator that inhibits estrogen actions in breast tissue. However, some breast cancers resist hormone-based therapy. Many molecular mechanisms allow breast cancers to lose estrogen sensitivity [29]. Breast cancers that lose estrogen sensitivity typically have a more aggressive course and poorly respond to chemotherapy [30]. A notable example is triple-negative breast cancer (negative for ERBB2 (Her2/neu), estrogen receptor, and progesterone receptor protein expression), which is typically an aggressive tumor that does not respond to targeted chemotherapy agents [30]. Interestingly, triple-negative breast cancers of women often express AR and might respond to ADT or AR blockade [30]. Yet, triple-negative breast cancers that lose AR expression often have characteristics of primitive basal-like cancers with poor clinical course [31]. This suggests that AR signaling may help induce new breast cancers, but "dedifferentiated" primitive cancers may downregulate AR expression because they are driven by hormone-independent mechanisms. Similar phenomena have been observed in other cancers that become independent of the signaling molecules that characterize cells from the same tissue of origin [32-34].

Hormone independence sometimes arises early in tumor progression. Breast ductal in situ carcinomas likely are precursors of invasive carcinomas. A few of these noninvasive tumors are "triple-negative" and express other markers characteristic of highly aggressive invasive breast cancers $[35,36]$. This evidence suggests that steroid hormone receptors and other important drivers of breast tissue growth can be lost early in the evolution of a few tumors. Resistance to drugs that affect hormone stimulation and signature signaling pathways fits into Hanahan and Weinberg's carcinogenesis and cancer progression paradigm [32]. Tumors are characterized by increasing independence from the growth factors that normally control cell proliferation in their tissue of origin. Independence from particular growth signals may occur early, as noted above. Due to their high mutation rate, other cancers unleash a repertoire of new growth mechanisms and acquire growth signal independence later in tumor evolution [32].

\section{UBC as an Endocrine Tumor}

Growing evidence indicates that UBC, like PCa, is driven by androgens and AR signaling. Distinct from most epithelial tissues, urothelium is derived from the urogenital sinus, which also gives rise to the prostate in males [37]. We speculate that the prostate and the urothelium share properties, such as AR-dependence. Many human UBC cell lines and $13-78 \%$ of UBC tumors express AR in both men and women [38-40]. Moreover, stromal cells express AR in about half of UBC tumors [38]. The $A R$ gene is polymorphic for exon 1 CAG repeat number, which encodes a tract of glutamine amino acid residues [41]. CAG repeat number inversely correlates with $A R$ transcription and AR signal strength [41]. This suggests that the CAG-encoded polyglutamine tract interferes with $A R$ transcription and possibly with AR protein function. Men with low AR CAG repeats are more likely to develop locally invasive or metastatic PCa [40,42]. Similarly, male UBC patients had fewer AR CAG repeats than control males, suggesting that AR signaling also may drive $\mathrm{UBC}[40,43]$. 
In addition to spontaneously arising cancers, carcinogen-driven UBC in mice were accelerated by AR and androgens. The carcinogen, BBN ( $N$-butyl- $N$-(4-hydroxybutyl)nitrosamine), more quickly induced UBC in male mice than in female mice. BBN-induced male UBC was reduced by surgical or medical ADT and an AR-blocking drug [40] or by knockout of the $A R$ gene [44]. Interestingly, $A R$ knockout protected both male and female mice from BBN exposure, eliminating UBC incidence and greatly reducing bladder hyperplasia [44]. Finasteride (a $5 \alpha$-reductase inhibitor that prevents the conversion of testosterone to the more potent androgen, DHT; Figure 1) was marginally protective [40]. In female mice, androgen treatment increased bladder tumor incidence. The significant ADT effect and the marginal protection offered by finasteride suggest an AR signaling threshold. $5 \alpha$-reductase inhibitors prevent conversion of testosterone to the more active DHT, but are associated with higher testosterone levels [45]. Therefore, mouse UBC might be driven equally by physiological male androgen signaling and by moderate androgen signaling found in the presence of $5 \alpha$-reductase inhibitors. This parallels findings in human PCa-men with the lowest $10 \%$ of testosterone levels were relatively protected from $\mathrm{PCa}$, but men with the highest testosterone levels had no increased risk compared to men with moderate levels [46]. Furthermore, testosterone replacement therapy does not increase PCa risk [47]. If there is an androgen threshold in UBC, we would speculate that the relatively high androgen levels in men impart a greater UBC risk. In summary, a growing body of evidence shows how $\mathrm{AR}$ and androgen signaling promote UBC development and progression. Based on this evidence, targeting AR is predicted to reduce $\mathrm{UBC}$ recurrence and progression.

Transcriptional coactivator proteins help mediate AR-dependent gene transcription and support AR protein stability [48]. The steroid hormone receptor coactivator, NCOA3 (AIB1), was overexpressed in about a third of human UBC cases, which was an independent predictor of poor progression-free survival in multivariate regression analysis [49]. Furthermore, NCOA3 knockdown slowed human tumor xenograft growth in mice and $N C O A 3$ enforced expression increased tumor growth [49]. SiRNA knockdown of coactivator RNA in AR-positive UBC cell lines decreased androgen-induced proliferation [39]. AR coactivators NCOA1, NCOA2, NCOA3, CREBBP, and EP300 were expressed in 86-100\% of UBCs, even though AR was present in a minority of UBCs $[39,40]$. The presence of these coactivators when AR was absent suggests that they cooperate in non-AR-directed transcription.

The mechanisms by which androgens and AR control UBC are not fully understood. UM-UC-3 UBC cells selected for AR expression had higher clonogenic growth and greater migration than parental UM-UC-3 cells after androgen treatment in vitro, suggesting that AR drives UBC growth and metastasis [50]. As in prostate cancer [48], some data suggest that UBC may initially present with androgen dependence but progressive UBC may lose this dependency $[40,51]$. Izumi et al. [52] reported that AR, estrogen receptor- $\alpha(E R \alpha)$, and $E R \beta$ nuclear staining were more frequent in normal-appearing urothelium than in UBC. In men receiving ADT, AR-negative UBC went on to recur in 12 of 28 patients $(43 \%)$, but AR-positive UBC recurred in only 11 of 44 patients (23\%). In multivariate analysis of men receiving ADT [52], only two factors were significant, UBC AR expression and UBC tumor number (single vs. multiple). This suggests that ADT delays or prevents UBC recurrence in AR-positive tumors (Table 1). AR expression level in normal urothelium did not correlate with tumor recurrence and tumor cell ER $\alpha$ and ER $\beta$ expression did not predict recurrence. In another study, Izumi et al. [53] investigated UBC recurrences in patients who were also treated for PCa (Table 1). UBC recurrence was less frequent in the ADT-treated PCa group (5-year actuarial recurrence-free survival: $76 \% v 40 \% ; p<0.001$ ). In those men with UBC recurrence, ADT was associated with fewer recurrence episodes (5-year cumulative recurrence: 0.44 vs. $1.54 ; p<0.001)$. Most patient characteristics would have been predicted to disfavor the ADT group (worse PCa disease, older age), but brachytherapy was higher in the non-ADT group and radiation is a UBC risk factor [54]. In addition, a greater percentage of the ADT group received BCG infusions [53], which prevent UBC recurrence [55-57]. Although intriguing, conclusions are weakened because the study was retrospective and 
multicenter [53]. Shiota et al. [58] followed 228 men for recurrence of bladder cancer for an average of 3.6 years; 32 of 196 men received ADT or dutasteride (a $5 \alpha$-reductase inhibitor) for concomitant PCa. UBC recurred in four men with ADT or dutasteride $(12.5 \%)$ and 59 men without (30.1\%). Progression to muscle-invasive cancer occurred in none of the men on ADT or dutasteride and in six men who were not on these therapies (3.1\%). ADT (or dutasteride) was associated with significantly decreased risk of intravesical recurrence (hazard $=0.4, p=0.024$ ). Although sample size was small and follow-up time was short, this study suggests that ADT or dutasteride may prevent UBC recurrence in high risk patients. In patients already diagnosed with $\mathrm{UBC}$, retrospective studies have suggest that both overall and cancer-specific survival were superior in $5 \alpha$-reductase inhibitor users [59]. ADT may protect UBC with low-risk disease, but not patients with high-risk disease [59]. This correlates with declining AR expression by more advanced UBC tumors $[40,50]$.

Table 1. Effects of Androgen-Based Therapy on UBC Recurrence, Progression, and Mortality.

\begin{tabular}{cccc}
\hline Treatment & Effect on UBC & Support & Ref. \\
\hline ADT & $\downarrow$ recurrence $\#$ & Yes & {$[52]$} \\
ADT & $\downarrow$ recurrence & Yes & {$[53]$} \\
ADT or $5 \alpha-\mathrm{R}^{\$}$ & $\downarrow$ recurrence, progression & Yes & {$[58]$} \\
$5 \alpha-\mathrm{R}$ & $\downarrow$ incidence, $\leftrightarrow$ mortality & Yes $/$ No & {$[60]$} \\
$5 \alpha-\mathrm{R}$ & $\downarrow$ recurrence & Yes & {$[61]$} \\
$5 \alpha-\mathrm{R}$ & $\leftrightarrow$ recurrence, $\downarrow$ deaths & No/Yes & {$[62]$} \\
$5 \alpha-\mathrm{R}$ & $\leftrightarrow$ incidence & No & {$[45]$} \\
\hline
\end{tabular}

*Support for the hypothesis that UBCs respond drug treatment. ${ }^{\#}$ Recurrence was less in men with $\mathrm{AR}^{+} \mathrm{UBC}^{\$}$ $5 \alpha-R, 5 \alpha$-reductase inhibitor drug.

Based on 13-year follow-up of the Prostate, Lung, Colorectal, and Ovarian (PLCO) database (Table 1), men who were treated with finasteride (a $5 \alpha$-reductase inhibitor) at any time during the survey had lower UBC incidence (hazard $=0.634$ ), when also controlling for age and smoking [60]. However, there was a non-significant trend toward higher UBC grades in finasteride users and there was no significant difference in UBC-caused mortality [60]. The retrospective study was limited because finasteride dose and some risk factors (such as alcohol consumption) were not known. In two retrospective insurance record reviews in Taiwan (Table 1), investigators found that $5 \alpha$-reductase inhibitors did [61] or did not [62] reduce the risk of UBC recurrence. One of the studies (Table 1) found that $5 \alpha-$ reductase inhibitors prevented UBC deaths [62]. Interestingly, amplification of the gene that encodes $5 \alpha$-reductase was found in $12 \%$ of UBC queried in the TCGA database [61]. In a systemic review, ADT or $5 \alpha$-reductase inhibitors had mixed results in preventing UBC [59]. Interpretation of these studies is difficult because of the expected lower complications of urinary tract infection and hematuria in $5 \alpha$-reductase inhibitor users that may have led to fewer exploratory cystoscopies and, therefore, fewer incidental UBC diagnoses. This may have decreased UBC discovery in the $5 \alpha$-reductase inhibitor group. Despite the number of manuscripts showing that ADT and $5 \alpha$-reductase inhibitors reduce UBC incidence or recurrence, it should be noted that most of these studies had methodological limitations [63].

A double-blind prospective study was conducted on subjects in the MTOPS trial [45]. Subjects were monitored for compliance, something that is impossible with retrospective studies. As expected, serum DHT levels were lower and testosterone levels were higher among the subjects treated with $5 \alpha$-reductase inhibitor drug [45]. UBC incidence was not statistically different in men with and without $5 \alpha$-reductase inhibitor treatment (Table 1 ). Thus, there is support for use of ADT in UBC, especially when the tumor expresses AR. However, the literature on $5 \alpha$-reductase inhibitor treatment is inconsistent (Table 1). Literature inconsistency correlates with weak findings in experimental animals [40]. One possible interpretation of these results is that there is a threshold effect of androgen signaling in promoting UBC - the moderate amount of androgen signaling retained in $5 \alpha$-reductase 
inhibitor users may be sufficient to promote UBC, whereas the lower level of androgen signaling under ADT may reduce UBC risk.

Researchers have investigated a possible correlation between AR expression and increased transformation of normal bladder urothelium to UBC. In a meta-analysis, AR status in UBC correlated neither with patient gender, nor with tumor size, stage, grade, or progression [51]. In contrast, three studies showed that lack of tumor AR expression was strongly associated (odds ratio, 0.41 ) with more frequent UBC recurrence [51], although discordant results have been reported [40,64]. Most studies showed that AR status did not predict survival [64]. Hsu et al. [65] found that bladder-specific AR knockout mice developed fewer and less aggressive BBN chemical-induced UBCs. They also showed that AR acted through a p53-mediated pathway, allowing more bladder cancer cells to survive apoptosis [65]. This suggests that AR signaling increases tumorigenesis and tumor cell survival. Luna-Velez et al. reported that AR expression was significantly lower in muscle-invasive disease than in non-muscle-invasive UBC; AR expression was the lowest in the most advanced T3 and T4 disease, compared with T1 UBC [50]. On the other hand, Mir et al. [66] did not find a significant AR-related difference in time to death or rate of recurrence in a study of almost 500 patients with UBC muscle-invasive tumors. Among the patients studied, $12.9 \%$ of the tumors expressed AR and there was no significant sex difference. It is likely that $\mathrm{AR}$ affects UBC in complex ways that depend on cancer stage. AR signaling seems to initiate more UBCs, but we do not know whether AR signaling causes more aggressive disease. Given that many tumors grow increasingly independent of hormones and signaling pathways during cancer progression [32], it would not be surprising if androgens drive early UBCs, but not late UBCs.

In a separate aspect of AR signaling, Miamoto's group [67] showed that androgens increased resistance to cisplatin-based chemotherapy of AR-expressing UBC cell lines. In a complementary fashion, AR-blocking drugs increased cisplatin sensitivity $[67,68]$. Among the mechanisms responsible, Miamoto's group [69] found that androgens reduced expression of an RNA- and ribosome-processing protein, BRIX1 (BXDC2), in UBC cell lines. Furthermore, AR and BRIX1 showed complementary expression patterns in UBC tissue sections [69]. Cisplatin-resistant cell lines increased BRIX1 expression [69], but BRIX1 mechanisms in UBC are not clear. Although treatment of cell lines in vitro cannot be directly translated to the clinic, these studies suggest that AR antagonists may act synergistically with cytotoxic chemotherapy in UBC patients. As mentioned above, intravesicular BCG treatment commonly follows NMIBC resection. BCG vaccination has many nonspecific effects, including nonspecific induction of "trained" immunity and lower levels of inflammatory serum proteins [70]. It is notable that the reduction of inflammatory proteins was much more pronounced in men than in women and correlated with pre-vaccine testosterone levels in males [70]. Preclinical data showed that BCG was more effective when $A R$ was downregulated or absent, or in the presence of AR antagonist drugs [71,72]. The mechanism is possibly related to the Rab27b vesicle protein, which may allow UBC to exocytose previously ingested BCG [71]. In a retrospective analysis of human biopsy samples, both AR and Rab27b protein expression correlated with higher UBC recurrence rates [71].

UBC incidence and the total number of UBC-related deaths are much higher in males than in females [3], but women suffer higher stage-for-stage progression and mortality than do men [73-75]. Sadly, some of the greater mortality in women may be related to delayed treatment or different treatment opportunities offered to females [74]. For example, urological investigation of hematuria is delayed in female patients compared with male patients. As an exception to that general finding, women may have a better cancer-specific mortality than men following neoadjuvant chemotherapy plus radical cystectomy [76]. This conclusion, which was based on two small studies [76], requires confirmation. However, women have worse outcomes following transurethral resection of NMIBC and post-surgery chemotherapy [74]. In early stage Ta tumors, women are more likely to have the GS1 UBC subtype. These tumors have high rates of proliferation, mutations, genetic instability, and 
loss of chromosome 9 or deletion of 9q [77]. These deletions remove TSC1, a negative regulator of the mechanistic target of rapamycin (mTOR). Consequently, GS1 NMIBCs have gene expression changes that suggest altered metabolism, including elevated glycolysis [77]. Consistent with overall worse outcomes for women, multivariate analysis suggested that female sex was a risk factor for recurrence after BCG therapy [74,78], despite the welldocumented superior responses by women to a variety of vaccines [79-84]. de Jong and colleagues [85] found that, compared with men, women were more likely to have the aggressive basal/squamous subtype, whereas men were more likely to have luminal papillary and neuroendocrine-like subtypes. It may be significant that advanced UBC in men had higher androgen response activity across all luminal subtypes, compared to advanced UBC in women [85]. These findings support the concept that androgens help initiate UBC. However, some UBCs progress to a more aggressive form, becoming androgen-independent through AR loss or other means. One molecular consequence of AR loss in advanced UBC is that AR suppresses transcription of CD44 [86], which encodes a cancer stem cell marker that mediates UBC aggression [87]. AR mRNA negatively correlated with CD44 mRNA in UBC, both before and after chemotherapy [86]. Due to lower androgen levels in women, it should not be surprising that the smaller numbers of UBC female patients are enriched for more aggressive androgen-independent cancers. In contrast to androgens, the role of estrogens in UBC is less clear. Estrogens appear to suppress UBC development but may promote UBC progression [74]. Treatment of mice with the selective estrogen receptor modulator, tamoxifen, greatly reduced bladder tumor formation and muscle-invasive tumors in female mice fed the BBN carcinogen [88]. Hsu et al. $[89,90]$ reported that female mice lacking ER $\beta$ were less susceptible to carcinogeninduced UBC, whereas female mice lacking ER $\alpha$ were more susceptible. These apparently discordant results suggest that there are distinct roles for $E R \alpha \alpha$ and $E R \beta \beta$ homodimers, in addition to $E R \alpha \beta$ heterodimers.

\section{Androgenic Immune Suppression}

Gender-based immune disparity is well-documented [81,91,92]. Men suffer more infectious disease complications [93,94] and cancers [3,95-97] than do women, including at elderly ages. Women generally respond better to vaccines, although exceptions exist [79-84]. Autoimmune disease can be attributed to excess immunity and women are more susceptible to the most common autoimmune diseases [83]. Sex differences are observed in children as well. Infant boys are significantly more susceptible to infections than infant girls, a difference that is attributed to the androgen surge that boys experience at birth [83,98-100]. In addition to androgens, male vs. female immune response differences might be linked to estrogens, progesterones, $\mathrm{X}$-linked genes, and socioeconomic factors. In the current pandemic, male gender has been found to be a strong risk factor for COVID-19 disease and death, whether or not overall SARS-CoV-2 infection rate is higher in men than in women [101,102].

Early hematopoietic precursor cells express AR RNA in mouse bone marrow and in human bone marrow and cord blood [103]. However, some differentiated hematopoietic cells lose AR expression [103]. Using immunohistochemistry, Mantalaris and colleagues [104] detected AR protein in several bone marrow elements, including stromal cells, endothelial cells, $\mathrm{M} \varphi$, and other myeloid cells (although not eosinophils). AR expression was affected neither by sex nor by age (range 1-92 years). However, Mantalaris et al. [104] did not detect AR protein in bone marrow lymphocytes.

\section{Androgens and Innate Immunity-Myeloid Cells}

Myeloid cells are pivotal in anti-cancer immunity [32,105-107]. Depending on the local cytokine and cellular microenvironment, myeloid cells promote tumor angiogenesis and growth and suppress immunity. Alternatively, myeloid cells present tumor antigens to $\mathrm{T}$ cells and cooperate with NK cells to eliminate cancer cells [32,105-115]. Developing myelocytes respond to androgens, but specific myeloid subsets become androgen-independent 
at distinct differentiation stages. The common myeloid progenitor is stated to express AR RNA [25]. The common dendritic cell and the granulocyte-macrophage progenitor do not express AR, but mature myeloid cells do, including macrophages $(\mathrm{M} \varphi)$, monocytes, neutrophils (both band cells and segmented), and mature mast cells [25,104].

Among the myeloid cells, $\mathrm{M} \varphi$ are particularly important because they regulate tissue homeostasis and produce several proinflammatory cytokines [108,114,116-121]. Myeloidspecific $A R$ gene deletion and AR-blocking enzalutamide reduced monocyte precursors in the mouse bone marrow [122]. AR knockout also reduced the proportion of classical monocytes [122], which are thought to enter tumor and inflammatory sites and develop into macrophages or dendritic cells. Gonadectomy elevated pro-inflammatory responses by increasing expression of toll-like receptor 4 (TLR4) by male murine $\mathrm{M} \varphi$ [123]. Some results, however, suggest that testosterone promotes specific proinflammatory cytokines in certain contexts [124-126]. Thus, testosterone and AR signaling may differentially affect $\mathrm{M} \varphi$ depending upon the $\mathrm{M} \varphi$ source, the type of stimulus, and the cytokine secreted. $\mathrm{M} \varphi$ cells involved in wound healing express AR. Wound healing is slower in males than in females, but healing has been shown to be accelerated by an AR antagonist, flutamide, and by myeloid-specific $A R$ gene deletion $[124,125]$. Importantly, wound healing correlated negatively with testosterone levels in elderly men [124].

Neutrophils, the most abundant blood leukocyte, respond rapidly to bacterial infections and many cancers [127]. Androgens promote neutrophil differentiation-AR-deficient mice, androgen insensitive mice, and AR blocker-treated patients are neutropenic [128,129]. Following treatment with stanozolol, a testosterone analog, female mice increased neutrophil maturation rate [130]. However, the mechanisms by which AR signaling affects neutrophil function have not been fully elucidated [131]. Some authors have shown that androgens suppress neutrophil production of proinflammatory cytokines and instead promote anti-inflammatory IL-10 production [132]. These data suggest that androgens promote neutrophil differentiation, but dampen neutrophil inflammatory actions.

Dendritic cells (DCs) present antigens to T cells and affect NK cell function [109-113,133,134]. DCs synthesize IL-15 and present it on their cell surface to stimulate NK cells and memory T cells to mature, divide, and survive [110,135-137]. DCs stimulate NK cells to synthesize granzyme B and become cytotoxic $[110,135,137,138]$. Only a few studies have addressed possible direct effects of AR and androgens on DCs, but, in general, they seem to depress DC immune function [25]. This is controversial because some investigators have shown that DCs do not express AR [139]. DCs isolated from male mice after brain LCMV infection were less activated than in female mice [140]. Male sex reduced expression of DC MHCII and CD86 [140]. These molecules, respectively, present antigens at the cell surface to CD4 T cells [141] and co-stimulate T cell CD28, which promotes T-cell differentiation and survival [142]. Castration increased expression of MHCII, CD86, and other co-stimulatory molecules [143].

\section{Androgens and Innate Immunity-NK Cells}

NK cells kill both virus-infected cells and cancer cells, including metastases, without antigen specificity or prior immunization [115,144-150]. Comprising $5-15 \%$ of blood lymphocytes in healthy people, NK lymphocytes are defined by CD56, CD16, or NKp46 (CD335) expression in the absence of the CD3 T-cell receptor [144-146]. NK cell activation is regulated by multiple receptors [144-146]. Cell surface MHC class I molecules (MHCI, termed HLA class I in humans) present antigenic peptides to CD8 cytolytic T lymphocytes, which then divide, secrete IFN- $\gamma$ and other cytokines, and kill antigen ${ }^{+}$cells $[141,151]$. In addition to stimulating CD8 T cells, MHCI molecules strongly modulate NK cell responses by engaging NK cell KIR, NKG2A, and LILRB1 inhibitory receptors [144,146,152,153]. NK cells also express many stimulatory receptors [144-146]. For example, NKG2D binds to stress-activated ligands that are preferentially expressed on tumor cells and virus-infected cells $[144,146,148,154]$. When confronting stress-activated ligand-positive tumor cells, antibody blockade of NKG2D prevents robust NK cell activation [154]. 
AR may affect NK cell development. Acyline-mediated chemical castration (ADT) for two weeks increased circulating NK cells in men [155]. Testosterone replacement prevented these changes. After 4 weeks of recovery from ADT, NK cell number returned to normal levels; CXCR1 and NKG2D expression did not significantly change [155]. These findings indicate that androgens control human NK cell numbers. In the elderly, the immature CD56 ${ }^{\text {bright }}$ to mature CD56 ${ }^{\mathrm{dim}} \mathrm{NK}$ cell ratio was significantly higher in women than in men [156]. Female CD56 ${ }^{\mathrm{dim}}$ NK cells had higher cytotoxic granule exocytosis in response to $\mathrm{K} 562$ tumor cells and higher IFN- $\gamma$ made in response to cross-linking of NKp46. Plasma IL-15, a cytokine required for NK cell development and survival, did not differ by gender [156]. Therefore, although the mechanisms of the gender differences were not identified, the results suggest that testosterone suppresses NK cell activity in elderly humans. We did not detect AR mRNA in either CD56 ${ }^{\text {bright }}$ or CD56 ${ }^{\text {dim }}$ peripheral blood NK cells (data not shown); therefore, the effects of testosterone on mature NK cells likely are indirect. We further investigated whether androgens affected NK cell activity in the context of cancer treatment. After obtaining informed consent, five men were studied before and after ADT for metastatic PCa. The study was IRB-approved and consistent with the Helsinki Declaration. Peripheral blood was removed by venipuncture and the ability of NK cells in a mononuclear cell preparation to produce a chemokine (MIP-1 $\beta$ ) was compared pre- and post-ADT. Both IL-15 and IL-12/IL-18 stimulated significantly higher MIP-1 $\beta$ responses post-ADT, with the IL-2-stimulated responses trending higher (Figure 2). Several stimuli failed to significantly increase IFN- $\gamma$ or cytotoxic responses post-ADT. This shows that NK cells from men receiving ADT were not globally activated, but selectively produced MIP- $1 \beta$ in response to IL-15 and IL-12/IL-18 cytokine stimuli. Although many changes take place with ADT initiation, including a reduction of PCa mass, our results are consistent with the hypothesis that androgens suppress NK cell MIP- $1 \beta$ responses to cytokines and that ADT relieves the suppression.

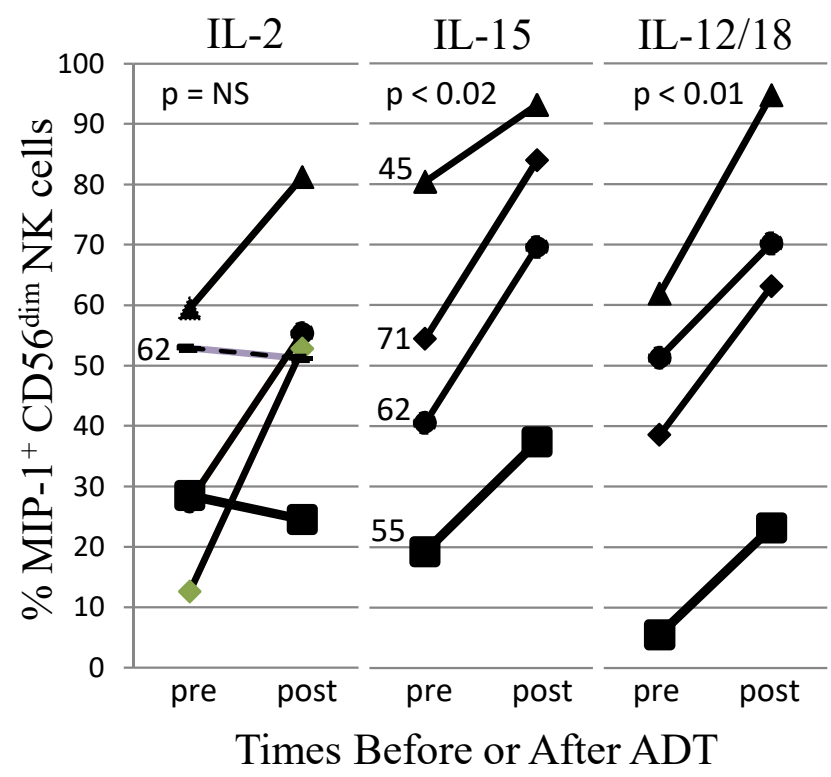

Figure 2. Blood from five patients was studied before and 92-96 days (or 51 days in one patient shown as a dashed line in IL-2 panel) after the start of ADT, which included Lupron ${ }^{\circledR}$, with or without additional ADT drugs. In all cases, short-term Casodex ${ }^{\circledR}$ pre-treatment was used to prevent a Lupron-associated testosterone flare. Peripheral blood mononuclear cells were stimulated for $20 \mathrm{~h}$ with IL-2 (200 U/mL), IL-15 (100 ng/mL), or IL-12/IL-18 (10/100 ng/mL), as indicated above each panel. The cells were harvested and NK cell intracellular MIP-1 $\beta$ was measured by flow cytometry, using standard methods [156]. Shown are responses by mature CD56 ${ }^{\text {dim }}$ NK cells. Each symbol represents responses by the same patient and patient age is indicated in the panels. Significance was assessed by paired student's $t$-test. NS = not significant. 


\section{Androgens and Adaptive Immunity-B Cells}

B cells both activate and carry out adaptive immunity. Firstly, B cells stimulate a special class of CD4 T follicular helper cells in the germinal center [157]. Later in the immune response, B cells develop into plasma cells that secrete antibody, which protects the host by several mechanisms [158]. In general, women produce relatively more antibody after vaccination $[80,81]$. Low testosterone levels in men predict more B cells and higher response to vaccines and to infection [80,83]. Research suggests that mature $B$ cells do not express AR; therefore these effects may be exerted by other leukocytes or on B-cell precursors when the AR is expressed [159-161]. Several lines of evidence show that AR signaling impedes B-cell development. [159,162-164]. Experiments with chimeric mice that expressed $A R$ exclusively on either stromal cells or lymphoid cells in the bone marrow showed that stromal cell $A R$ is essential to inhibit the B-cell lymphopoiesis typically observed with androgen treatment [164]. This suggests that the B-cell response to androgens is mediated by stromal cells. In contrast to these findings, B-cell-specific $A R$ knockouts have been shown to elevate B-cell lymphopoiesis, suggesting that mouse B-cell precursors are direct androgen targets [164]. The effect of the general AR knockout was more pronounced than the B-cell-specific $A R$ knockout, suggesting that both B-cell and stromal $A R$ suppress B-cell development. Further studies have shown that DHT causes stromal cells to produce transforming growth factor- $\beta$, an anti-inflammatory cytokine that dampens immune responses. Relevant to this discussion, transforming growth factor $\beta$ suppresses IL-7 production, a cytokine that is required for B-cell proliferation and differentiation [165].

\section{Androgens and Adaptive Immunity-T Cells}

In comparison with B cells, T-cell response to androgens is more sustained and direct [84]. AR is highly expressed in lymphoid precursor cells and in supporting cellsmarrow stromal cells and thymic epithelial cells [166]. It was established more than a century ago that castration causes thymic hypertrophy, which suggests that androgens regulate T-cell development [91,167-170]. Although AR has been detected in thymocytes, experiments with chimeric mice showed that thymic involution required AR expression in stromal cells, but not in bone-marrow-derived T lymphocyte precursors [166,169]. In a key molecular step, androgens reduce thymic epithelial expression of $\delta$-like 4 , a notch ligand that is required for T-cell maturation [91,171].

Mature T cells appear to express both classic cytoplasmic AR and a plasma membrane androgen receptor [13-15,161,172-174]. Exogenous androgen treatment skews mouse T-cell activation, proliferation, and differentiation, and inhibits T-cell-dependent antibody production $[10,25,80,83]$. These effects are likely due to a combination of intrinsic T-cell effects [172] and depression of antigen-presenting cell MHC and costimulatory molecule expression or cytokine production [123-126,140,143]. Thus, androgens affect both T-lymphocyte development and mature T cells.

The study of androgen regulation is complicated by the many classes of $\mathrm{T}$ cells, each with unique functions. CD4 T-helper 1 (Th1) cells are proinflammatory and produce cytokines that stimulate cell-mediated and innate responses, which help prevent tumors and clear intracellular bacteria and viruses [175]. Kissick et al. [172] showed that testosterone reduced CD4 Th1 differentiation by upregulating protein tyrosine phosphatase, non-receptor type 1 (Ptpn1), which negatively regulates many cellular processes. $T$ cells expressed less Ptpn1 in PCa patients undergoing ADT than in control PCa patients [172] and (Haydn T. Kissick, personal communication 12 April 2019). CD4 T-helper 2 (Th2) cells control humoral immunity and the clearance of extracellular pathogens [175]. As with Th1 cells, androgens diminish Th2 responses [176]. Th2 cells also quell inflammatory immune responses by secreting anti-inflammatory cytokines [175,177]. Experimental autoimmune encephalomyelitis is a commonly used model for multiple sclerosis, a demyelinating autoimmune disease. In experimental autoimmune encephalomyelitis cell culture and mouse models, androgen treatment increased IL-10 production and decreased 
demyelinating disease in female mice [178]. The underlying mechanisms are not known, but IL-10 generally seems to protect against autoimmune disorders [177]. Androgens stimulated mast cells, which activated innate lymphoid cell type 2 (ILC-2) cells, which in turn activated a Th2-like response $[179,180]$. Interestingly, testosterone, Fc receptor cross-linking, and Mycobacterium tuberculosis all induce IL-33 production in male, but not in female, bone-marrow-derived mast cells [179]. In specific inflammatory diseases, IL-33-driven Th2 responses ameliorate disease pathology [181].

Regulatory $\mathrm{T}$ cells $\left(\mathrm{T}_{\text {reg }}\right)$ modulate the immune response by reducing inflammation and by modulating response to self-antigens [182,183]. Regulatory $\mathrm{T}$ cells put the brakes on a variety of cells, including NK cells $[184,185]$. Androgens increase $\mathrm{T}_{\text {reg }}$ cells in vivo and in vitro. Waleki et al. showed that this modulation was related to androgen-dependent acetylation of histone $\mathrm{H} 4$ at the FOXP3 locus, a gene that is needed for $\mathrm{T}_{\text {reg }}$ cells to differentiate in the thymus and to function in the peripheral tissue $[174,186]$. Androgen modulation of FoxP3 expression is one of many mechanisms by which androgens suppress immunity.

\section{Chromosomal Effects on UBC}

In healthy females, each cell randomly silences one $X$ chromosome at an early stage of embryogenesis [187]. However, $X$ chromosome silencing is incomplete and about $15-25 \%$ of these genes are transcribed to at least the $10 \%$ level on the active $X$, and a few at nearly $100 \%[188,189]$. Some genes always escape complete inactivation, and some vary between XX females. Escape from complete silencing also differs by tissue and stage of development and increases with entry into the cell cycle $[190,191]$. Thus, compared to males, females express significantly more mRNA from certain X-linked genes. UBC and other solid tumor incidence are increased in patients with Turner syndrome, which is characterized by XO, a single sex chromosome [192,193]. Similarly, solid tumor incidence is decreased in Klinefelter syndrome patients, who carry at least $2 \mathrm{X}$ chromosomes and $1 \mathrm{Y}$ chromosome, have small testicle size, and reduced testosterone [192]. As in females, $X$ chromosome inactivation is incomplete on supernumerary X chromosomes in Klinefelter males [194]. Both Turner syndrome and Klinefelter syndrome patients have altered sex hormone levels, so sex hormones, $\mathrm{X}$ chromosome number, or both might affect cancer risk. To separate biological sex and associated hormone expression from sex chromosome composition, investigators have created "four core genotype" mice [195]. These animals have the sexdetermining SRY gene deleted on the Y chromosome and inserted into an autosome, allowing biological sex (and sex hormones) to be separated from $X$ and $Y$ chromosome composition. Using the "four core genotype" mice, Kaneko and Li [196] studied UBC responses to the BBN carcinogen. $X Y$ male mice were most susceptible, followed in order by $X X$ males, $X Y$ females, and $X X$ females. Survival was significantly different in each group. Thus, both biological sex and sex chromosome composition contributed to UBC risk in mice. Investigating the mechanism involved, Kaneko and Li [196] showed that the X-linked lysine demethylase 6A (KDM6A) gene is expressed more highly in the urothelium of XX males and females than in the urothelium of XY males and females [196]. This is because females express KDM6A from both $\mathrm{X}$ chromosomes, escaping silencing $[197,198]$. Mechanistically, KDM6A reverses the action of EZH2 methylation, which inhibits the transcription of multiple genes $[199,200]$. These mouse findings are relevant to human disease. UBC from female patients had more KDM6A expression than did UBC from male patients $[77,196]$. Furthermore, low tumor KDM6A expression was associated with higher UBC tumor stage in women, but not in men. KDM6A mutations and low mRNA levels correlated with poor disease-free survival in women, but not in men [196]. KDM6A is mutated in several cancers, but the highest rates of mutation (20-29\%) are found in UBC, with most of the genetic alterations being pathogenic nonsense, frameshift, or splice site mutations $[199,201-203]$. An exciting finding is that loss of KDM6A in a UBC xenograft model predisposed tumor cells to epigenetic therapy, which diminished in vivo tumor growth and increased natural killer cell attack [203]. In addition to KDM6A, Dunford et al. [204] found five other X-linked 
genes (ATRX, CNKSR2, DDX3X, KDM5C, and MAGEC3) with loss of function mutations or copy number changes that were more frequent in men than in women in many cancer types. This sex-linked association was highly significant, as it was found in 6 out of $783 \mathrm{X}$ chromosome genes but in zero of 18,055 genes from autosome chromosomes or pseudoautosomal X chromosome regions [204]. Although we do not fully understand how most of these $X$ chromosome genes contribute to cancer, their incomplete allelic inactivation may protect women.

The Y chromosome also affects cancer risk, but functions differently [205]. From an analysis of 1153 elderly men, partial loss of the $Y$ chromosome in peripheral blood was associated with increased non-hematological cancer mortality. Men who had lost the $\mathrm{Y}$ chromosome had a median survival time of 5.5 years shorter than patients who had an intact $\mathrm{Y}$ chromosome [205]. More relevant to this discussion, the $\mathrm{Y}$ chromosome is uniformly missing from many male UBC cases [206]. In other cancers with a defective KDM6A allele on the $\mathrm{X}$ chromosome, the $\mathrm{Y}$ chromosome may be present in the cell, but may severely limit gene expression [202]. These findings suggest the possibility of one or more $\mathrm{Y}$-linked tumor suppressor genes. One candidate for the $\mathrm{Y}$ chromosome tumor suppressor gene is KDM6C (also known as UTY), which is a paralog of KDM6A, mentioned above. Ahn et al. [207] found that $23 \%$ of male UBC cases had deleted KDM6C; the KDM6C deletion rate was $67 \%$ in UBC that also had an $\mathrm{X}$ chromosome $K D M 6 A$ mutation. Other investigators found $K D M 6 C$ copy number loss or Y chromosome loss in $12-42 \%$ of male $\mathrm{UBC}$ cases and this was more common in UBCs that carried KDM6A mutations [77,199]. Thus, the $\mathrm{X}$ chromosome KDM6A and the $\mathrm{Y}$ chromosome KDM6C each may suppress tumor growth and partially compensate for each other in males.

\section{Sex Differences Not Directly Attributed to Hormones or Sex Chromosomes}

Some sex-related differences do not appear to be directly related to sex hormone differences or sex chromosomes. For example, chromosome 3 VGLL3 shows female-biased expression in skin, salivary glands, and in monocytes [208]. Keratinocytes from female subjects expressed more VGLL3 RNA, whether there was estradiol, testosterone, or no sex hormone in culture [208]. VGLL3 is of interest as it may act as a tumor suppressor gene in epithelial ovarian cancer [209], but VGLL3 expression is a marker for poor outcome in stomach adenocarcinoma and in PCa [210,211]. Therefore, VGLL3 is differentially expressed by sex in some tissues and alters tumor outcome. In another example, Sabag et al. [212] found that hemizygous deletion of the chromosome 10 EGR2 (Krox20) gene, whether in whole animals or in myeloid cells, increased bone resorption by osteoclasts in female mice, but not in male mice. The phenomenon continued to be manifested in preosteoclast cell lines cultured several days in vitro in the absence of any sex hormones. However, further investigation [212] showed that the sex differences were manifested only in preosteoclast cells that had been derived from post-pubertal mice ( 8 weeks old) but not harvested from mice before puberty (4 weeks old). These and other data $[213,214]$ suggest that sex hormones cause epigenetic differences in the genomes of male and female animals, which persist long after sex hormones are removed. It is relevant to note that most genes that show sex-specific expression are driven by distinct sets of transcription factors in male and female tissues, even when the transcription factor levels do not vary by sex [215]. This strongly suggests that the sex differences establish distinct epigenetic landscapes, which persist after direct sex hormone action. Many of the differentially expressed sex-specific proteins are involved in methylation and presumably control epigenetic gene expression [215].

\section{UBC and Natural Killer Cells}

NK cells are the most common leukocyte in UBC tumors [216]. Using gene expression data to deduce immune cell infiltration, several groups have reported that the presence of NK cells predicts better UBC outcomes [203,217-220]. Importantly, the level of CD56 ${ }^{\text {bright }}$ NK cells correlates with both cancer-specific survival and overall survival [216]. These data are consistent with the idea that NK cells slow UBC progression. This idea is reinforced by 
findings that epigenetic therapy of KDM6A-deficient UBCs caused NK cell attack and tumor regression in a preclinical model [203]. As mentioned above, NMIBC is often treated with intravesical BCG instillation [55-57]. Now used for more than 40 years, BCG intravesicular infusion is the longest continuously used cancer immunotherapy [55-57]. NK cells are among many immune and non-immune cells that are required for BCG immunotherapy success [55,221-225]. In other settings, BCG vaccination induces an elevated "trained immunity" against multiple pathogens, including elevated in vitro NK cell responses against non-cross-reactive microbes [226]. Surprisingly, intravesicular infusion of cytokineactivated healthy donor human NK cells were reported to eliminate orthotopic human UBC mouse xenografts [225]. If this study is confirmed and expanded to human patients, it would suggest the potential for NK cell-based therapy.

UBC patient NK cells differ from those of healthy subjects. NK cells from UBC patients expressed low levels of L-selectin (CD62L), which allows lymphocyte circulation through lymph nodes, and low levels of stimulatory NKp30, NKp44, and NKp80 natural cytotoxicity receptors, which are crucial for target cell killing and other NK cell activities [146,225,227]. IL-2 boosts NK cell responses in cancer patients [228]. Following subcutaneous IL-2 injection, circulating NK cell number increases [229]. Importantly, some melanomas and kidney cancers respond to IL-2 injections [230]. However, IL-2 is a strong activator of regulatory T cells, which dampen immune responses by both T cells and NK cells [183,228,231,232]. IL-15 is an alternative cytokine because it signals NK cells and memory T cells though the same receptor $\beta$ and $\gamma$ chains as IL-2, but it renders effector cells refractory to regulatory T-cell suppression [233-235]. Using NK cells as a therapeutic agent, healthy donor NK cells were stimulated in vitro and then infused into hematopoietic stem cell transplant patients, with NK cell responses boosted by IL-2 injection. This combined treatment prevented acute myeloid leukemia relapse [236].

CSCs drive cancer progression and long-term proliferation by maintaining an undifferentiated state and replacing partially differentiated cancer cells [32,237-241]. CSCs resist radiation and many chemotherapeutic drugs, and account for metastases and posttreatment tumor relapse [32,237,238]. NK cells preferentially target CSCs [225,242-245], which suggests a possible therapeutic approach. UBC-derived NK cells killed the RT4 UBC cell line much more effectively after blocking MHCI [216], consistent with functional MHCI-specific inhibitory receptors on UBC tumor-infiltrating NK cells. Although CSCs may have relatively low or high MHCI expression, CSCs are NK susceptible because they express abundant stimulatory ligands [242-245]. The NK-stimulating ligands expressed by CSC include NKG2D ligands: MHC class I chain-related protein A and B (MICA and MICB) and ULBP1. Killing of CSCs by NK cell sis primarily controlled through the interaction of the NKG2D receptor and its ligands $[225,245]$. In mouse models, NK cells significantly decreased UBC CSC number [225]. These data suggest that NK cells kill CSC and thereby prevent bladder cancer recurrence.

\section{Conclusions}

In most non-reproductive tissues, men are more likely than women to develop cancer and die of disease, and UBC is an outstanding example. Gender disparity has many potential causes, including androgen-induced immunosuppression, androgen-induced urothelial and neoplastic proliferation, greater male exposure to carcinogens, and the protective effects of $X$ chromosome genes in females. We predict that better understanding the gender differences will to lead to more effective treatments in both men and in women. Suppression of androgens [40] may reduce NMIBC recurrence, progression, and mortality in men, and possibly in women. Knowledge that KDM6A and KDM6C are under-expressed in UBC suggests that reducing EZH2 activity will effectively treat KDM6A/KDM6Cdefective UBC in both sexes $[199,200]$. Boosting immunity, especially NK cell immunity, may lead to better outcomes in both sexes, especially in men. Although this review largely focused on biological sex, social factors also are important: women often receive delayed diagnostic testing and disparate treatment options. Finally, when urologists 
recognize that females and males are sometimes treated differently [74], outcomes may improve. We believe that a better understanding of gender-specific disparities in UBC, at the genetic, molecular, cellular, clinical, and cultural levels, will lead to more safe and effective treatments for both male and female UBC patients. More research is urgently needed.

Author Contributions: C.T.L. conceived of the manuscript, reviewed literature, and wrote the manuscript; L.L. reviewed literature and wrote the manuscript; S.R.P. performed the experiments, reviewed literature, and edited the manuscript; M.S. reviewed literature and edited the manuscript; P.W. recruited patients. All authors have read and agreed to the published version of the manuscript.

Funding: Department of Pathology and Laboratory Medicine, University of Kentucky. The UK Flow Cytometry and Immune Monitoring core facility is supported in part by the Office of the Vice President for Research, the Markey Cancer Center, and an NCI Center Core Support Grant (P30 CA177558) to the University of Kentucky Markey Cancer Center.

Institutional Review Board: The trial was conducted with IRB approval (\#49275) under supervision of the Markey Cancer Center.

Informed Consent Statement: Informed consent was obtained from all research subjects.

Data Availability Statement: Data will be made available upon request to the first author.

Acknowledgments: We thank William St. Clair for help with patient recruitment and Natasha Kyprianou and Rachel Stewart for comments and suggestions. We thank the Markey Cancer Center's Research Communications Office for graphic design assistance.

Conflicts of Interest: The authors declare no conflict of interest.

\section{References}

1. Sandberg, S. Lean In: Women, Work, and the Will to Lead; Deckle Edge, Alfred A. Knopf: New York, NY, USA, 2013.

2. Bladder. Available online: https://seer.cancer.gov/statfacts/html/urinb.html (accessed on 28 October 2021).

3. Siegel, R.L.; Miller, K.D.; Fuchs, H.E.; Jemal, A. Cancer Statistics, 2021. CA Cancer J. Clin. 2021, 71, 7-33. [CrossRef] [PubMed]

4. Hartge, P.; Harvey, E.B.; Linehan, W.M.; Silverman, D.T.; Sullivan, J.W.; Hoover, R.N.; Fraumeni, J.F. Unexplained Excess Risk of Bladder Cancer in Men. J. Natl. Cancer Inst. 1990, 82, 1636-1640. [CrossRef]

5. Cambier, S.; Sylvester, R.J.; Collette, L.; Gontero, P.; Brausi, M.A.; van Andel, G.; Kirkels, W.J.; Silva, F.C.; Oosterlinck, W.; Prescott, S.; et al. EORTC nomograms and risk groups for predicting recurrence, progression, and disease-specific and overall survival in non-muscle-invasive stage Ta-T1 urothelial bladder cancer patients treated with 1-3 years of maintenance Bacillus Calmette-Guerin. Eur. Urol. 2016, 69, 60-69. [CrossRef]

6. Peyromaure, M.; Zerbib, M. T1G3 transitional cell carcinoma of the bladder: Recurrence, progression and survival. BJU Int. 2004, 93, 60-63. [CrossRef]

7. Sievert, K.D.; Amend, B.; Nagele, U.; Schilling, D.; Bedke, J.; Horstmann, M.; Hennenlotter, J.; Kruck, S.; Stenzl, A. Economic aspects of bladder cancer: What are the benefits and costs? World J. Urol. 2009, 27, 295-300. [CrossRef]

8. James, A.C.; Gore, J.L. The costs of non-muscle invasive bladder cancer. Urol. Clin. N. Am. 2013, 40, 261-269. [CrossRef] [PubMed]

9. Davey, R.A.; Grossmann, M. Androgen Receptor Structure, Function and Biology: From Bench to Bedside. Clin. Biochem. Rev. 2016, 37, 3-15.

10. Henze, L.; Schwinge, D.; Schramm, C. The effects of androgens on T cells: Clues to female predominance in autoimmune liver diseases? Front. Immunol. 2020, 11, 1567. [CrossRef]

11. Thomas, P.; Pang, Y.; Dong, J. Membrane androgen receptor characteristics of human ZIP9 (SLC39A) zinc transporter in prostate cancer cells: Androgen-specific activation and involvement of an inhibitory G protein in zinc and MAP kinase signaling. Mol. Cell Endocrinol. 2017, 447, 23-34. [CrossRef] [PubMed]

12. Thomas, P.; Pang, Y.; Dong, J.; Berg, A.H. Identification and characterization of membrane androgen receptors in the ZIP9 zinc transporter subfamily: II. Role of human ZIP9 in testosterone-induced prostate and breast cancer cell apoptosis. Endocrinology 2014, 155, 4250-4265. [CrossRef] [PubMed]

13. Benten, W.P.; Becker, A.; Schmitt-Wrede, H.P.; Wunderlich, F. Developmental regulation of intracellular and surface androgen receptors in T cells. Steroids 2002, 67, 925-931. [CrossRef]

14. Benten, W.P.; Lieberherr, M.; Giese, G.; Wrehlke, C.; Stamm, O.; Sekeris, C.E.; Mossmann, H.; Wunderlich, F. Functional testosterone receptors in plasma membranes of T cells. FASEB J. 1999, 13, 123-133. [CrossRef]

15. Benten, W.P.; Lieberherr, M.; Sekeris, C.E.; Wunderlich, F. Testosterone induces Ca2+ influx via non-genomic surface receptors in activated T cells. FEBS Lett. 1997, 407, 211-214. [CrossRef] 
16. Lee, L.F.; Louie, M.C.; Desai, S.J.; Yang, J.; Chen, H.W.; Evans, C.P.; Kung, H.J. Interleukin-8 confers androgen-independent growth and migration of LNCaP: Differential effects of tyrosine kinases Src and FAK. Oncogene 2004, 23, 2197-2205. [CrossRef]

17. Ueda, T.; Bruchovsky, N.; Sadar, M.D. Activation of the androgen receptor N-terminal domain by interleukin-6 via MAPK and STAT3 signal transduction pathways. J. Biol. Chem. 2002, 277, 7076-7085. [CrossRef] [PubMed]

18. Salmi, S.; Santti, R.; Gustafsson, J.A.; Makela, S. Co-localization of androgen receptor with estrogen receptor beta in the lower urinary tract of the male rat. J. Urol. 2001, 166, 674-677. [CrossRef]

19. Pelletier, G. Localization of androgen and estrogen receptors in rat and primate tissues. Histol. Histopathol. 2000, 15, 1261-1270.

20. Rosenzweig, B.A.; Bolina, P.S.; Birch, L.; Moran, C.; Marcovici, I.; Prins, G.S. Location and concentration of estrogen, progesterone, and androgen receptors in the bladder and urethra of the rabbit. Neurourol. Urodyn. 1995, 14, 87-96. [CrossRef]

21. Abdel-Hamid, A.A.; Ali, E.M. Effect of testosterone therapy on the urinary bladder in experimental hypogonadism of rats. J. Mol. Histol. 2015, 46, 263-272. [CrossRef]

22. Huggins, C. Effect of orchiectomy and irradiation on cancer of the prostate. Ann. Surg. 1942, 115, 1192-1200. [CrossRef]

23. Huggins, C.; Hodges, C.V. Studies on prostatic cancer. I. The effect of castration, of estrogen and of androgen injection on serum phosphatases in metastatic carcinoma of the prostate. Cancer Res. 1941, 1, 293-297.

24. Saad, F.; Fizazi, K. Androgen deprivation therapy and secondary hormone therapy in the management of hormone-sensitive and castration-resistant prostate vancer. Urology 2015, 86, 852-861. [CrossRef] [PubMed]

25. Gubbels Bupp, M.R.; Jorgensen, T.N. Androgen-induced immunosuppression. Front. Immunol. 2018, 9, 794. [CrossRef] [PubMed]

26. Qin, J.; Liu, X.; Laffin, B.; Chen, X.; Choy, G.; Jeter, C.R.; Calhoun-Davis, T.; Li, H.; Palapattu, G.S.; Pang, S.; et al. The PSA ${ }^{-/ l o}$ prostate cancer cell population harbors self-renewing long-term tumor-propagating cells that resist castration. Cell Stem. Cell 2012, 10, 556-569. [CrossRef]

27. Schroeder, A.; Herrmann, A.; Cherryholmes, G.; Kowolik, C.; Buettner, R.; Pal, S.; Yu, H.; Muller-Newen, G.; Jove, R. Loss of androgen receptor expression promotes a stem-like cell phenotype in prostate cancer through STAT3 signaling. Cancer Res. 2014, 74, 1227-1237. [CrossRef] [PubMed]

28. Ojo, D.; Lin, X.; Wong, N.; Gu, Y.; Tang, D. Prostate cancer stem-like cells contribute to the development of castration-resistant prostate cancer. Cancers 2015, 7, 2290-2308. [CrossRef]

29. Lee, J.-Y.; Kong, G. MEL-18, a tumor suppressor for aggressive breast cancer. Oncotarget 2015, 6, 15710-15711. [CrossRef] [PubMed]

30. Garrido-Castro, A.C.; Lin, N.U.; Polyak, K. Insights into molecular classifications of triple-negative breast cancer: Improving patient selection for treatment. Cancer Discov. 2019, 9, 176-198. [CrossRef]

31. Riaz, N.; Idress, R.; Habib, S.; Lalani, E.N. Lack of androgen receptor expression selects for basal-like phenotype and is a predictor of poor clinical outcome in non-metastatic triple negative breast cancer. Front. Oncol. 2020, 10, 1083. [CrossRef]

32. Hanahan, D.; Weinberg, R.A. Hallmarks of cancer: The next generation. Cell 2011, 144, 646-674. [CrossRef]

33. James, C.; Ugo, V.; Le Couédic, J.-P.; Staerk, J.; Delhommeau, F.; Lacout, C.; Garçon, L.; Raslova, H.; Berger, R.; Bennaceur-Griscelli, A.; et al. A unique clonal JAK2 mutation leading to constitutive signalling causes polycythaemia vera. Nature 2005, 434, 1144-1148. [CrossRef]

34. Reischmann, N.; Andrieux, G.; Griffin, R.; Reinheckel, T.; Boerries, M.; Brummer, T. BRAFV600E drives dedifferentiation in small intestinal and colonic organoids and cooperates with mutant p53 and Apc loss in transformation. Oncogene 2020, 39, 6053-6070. [CrossRef] [PubMed]

35. Bryan, B.B.; Schnitt, S.J.; Collins, L.C. Ductal carcinoma in situ with basal-like phenotype: A possible precursor to invasive basal-like breast cancer. Mod. Pathol. 2006, 19, 617-621. [CrossRef]

36. Dabbs, D.J.; Chivukula, M.; Carter, G.; Bhargava, R. Basal phenotype of ductal carcinoma in situ: Recognition and immunohistologic profile. Mod. Pathol. 2006, 19, 1506-1511. [CrossRef] [PubMed]

37. Schoenwolf, G.C.; Bleyl, S.B.; Brauer, P.R.; Francis-West, P.H. Larsen's Human Embryology, 5th ed.; Elsevier Sanders: Philadelphia, PA, USA, 2015; pp. 375-428.

38. Boorjian, S.; Ugras, S.; Mongan, N.P.; Gudas, L.J.; You, X.; Tickoo, S.K.; Scherr, D.S. Androgen receptor expression is inversely correlated with pathologic tumor stage in bladder cancer. Urology 2004, 64, 383-388. [CrossRef]

39. Boorjian, S.A.; Heemers, H.V.; Frank, I.; Farmer, S.A.; Schmidt, L.J.; Sebo, T.J.; Tindall, D.J. Expression and significance of androgen receptor coactivators in urothelial carcinoma of the bladder. Endocr.-Relat. Cancer 2009, 16, 123-137. [CrossRef]

40. Li, P.; Chen, J.; Miyamoto, H. Androgen receptor signaling in bladder cancer. Cancers 2017, 9, 20. [CrossRef]

41. Chamberlain, N.L.; Driver, E.D.; Miesfeld, R.L. The length and location of CAG trinucleotide repeats in the androgen receptor N-terminal domain affect transactivation function. Nucleic Acids Res. 1994, 22, 3181-3186. [CrossRef]

42. Giovannucci, E.; Stampfer, M.J.; Krithivas, K.; Brown, M.; Dahl, D.; Brufsky, A.; Talcott, J.; Hennekens, C.H.; Kantoff, P.W. The CAG repeat within the androgen receptor gene and its relationship to prostate cancer. Proc. Natl. Acad. Sci. USA 1997, 94, 3320-3323. [CrossRef]

43. Teng, X.Y.; Liu, G.Q.; Diao, X.L.; Wu, Z.Y.; Li, L.; Zhang, W.; Zhang, X.; Su, Q. CAG repeats in the androgen receptor gene are shorter in patients with pulmonary, esophageal or bladder carcinoma and longer in women with uterine leiomyoma. Oncol. Rep. 2010, 23, 811-818. 
44. Miyamoto, H.; Yang, Z.; Chen, Y.T.; Ishiguro, H.; Uemura, H.; Kubota, Y.; Nagashima, Y.; Chang, Y.J.; Hu, Y.C.; Tsai, M.Y.; et al. Promotion of bladder cancer development and progression by androgen receptor signals. J. Natl. Cancer Inst. 2007, 99, 558-568. [CrossRef]

45. Sathianathen, N.J.; Fan, Y.; Jarosek, S.L.; Lawrentschuk, N.L.; Konety, B.R. Finasteride does not prevent bladder cancer: A secondary analysis of the Medical Therapy for Prostatic Symptoms Study. Urol. Oncol. 2018, 36, 338.e13-338.e17. [CrossRef] [PubMed]

46. Watts, E.L.; Appleby, P.N.; Perez-Cornago, A.; Bueno-de-Mesquita, H.B.; Chan, J.M.; Chen, C.; Cohn, B.A.; Cook, M.B.; Flicker, L.; Freedman, N.D.; et al. Low free testosterone and prostate cancer risk: A collaborative analysis of 20 prospective studies. Eur. Urol. 2018, 74, 585-594. [CrossRef]

47. Walsh, T.J.; Shores, M.M.; Krakauer, C.A.; Forsberg, C.W.; Fox, A.E.; Moore, K.P.; Korpak, A.; Heckbert, S.R.; Zeliadt, S.B.; Kinsey, C.E.; et al. Testosterone treatment and the risk of aggressive prostate cancer in men with low testosterone levels. PLoS ONE 2018, 13, e0199194. [CrossRef] [PubMed]

48. Nakazawa, M.; Paller, C.; Kyprianou, N. Mechanisms of therapeutic resistance in prostate cancer. Curr. Oncol. Rep. 2017, 19, 13. [CrossRef]

49. Tong, Z.T.; Wei, J.H.; Zhang, J.X.; Liang, C.Z.; Liao, B.; Lu, J.; Fan, S.; Chen, Z.H.; Zhang, F.; Ma, H.H.; et al. AIB1 predicts bladder cancer outcome and promotes bladder cancer cell proliferation through AKT and E2F1. Br. J. Cancer 2013, 108, 1470-1479. [CrossRef]

50. Luna-Velez, M.V.; Dijkstra, J.J.; Heuschkel, M.A.; Smit, F.P.; van de Zande, G.; Smeets, D.; Sedelaar, J.M.; Vermeulen, M.; Verhaegh, G.W.; Schalken, J.A. Androgen receptor signalling confers clonogenic and migratory advantages in urothelial cell carcinoma of the bladder. Mol. Oncol. 2021, 15, 1882-1900. [CrossRef] [PubMed]

51. Sanguedolce, F.; Cormio, L.; Carrieri, G.; Calo, B.; Russo, D.; Menin, A.; Pastore, A.L.; Greco, F.; Bozzini, G.; Galfano, A.; et al. Role of androgen receptor expression in non-muscle-invasive bladder cancer: A systematic review and meta-analysis. Histol. Histopathol. 2020, 35, 423-432.

52. Izumi, K.; Ito, Y.; Miyamoto, H.; Miyoshi, Y.; Ota, J.; Moriyama, M.; Murai, T.; Hayashi, H.; Inayama, Y.; Ohashi, K.; et al. Expression of androgen receptor in non-muscle-invasive bladder cancer predicts the preventive effect of androgen deprivation therapy on tumor recurrence. Oncotarget 2016, 7, 14153-14160. [CrossRef]

53. Izumi, K.; Taguri, M.; Miyamoto, H.; Hara, Y.; Kishida, T.; Chiba, K.; Murai, T.; Hirai, K.; Suzuki, K.; Fujinami, K.; et al. Androgen deprivation therapy prevents bladder cancer recurrence. Oncotarget 2014, 5, 12665-12674. [CrossRef]

54. Keehn, A.; Ludmir, E.; Taylor, J.; Rabbani, F. Incidence of bladder cancer after radiation for prostate cancer as a function of time and radiation modality. World J. Urol. 2017, 35, 713-720. [CrossRef]

55. Alexandroff, A.B.; Jackson, A.M.; O’Donnell, M.A.; James, K. BCG immunotherapy of bladder cancer: 20 years on. Lancet 1999, 353, 1689-1694. [CrossRef]

56. Sylvester, R.J.; van der, M.A.; Lamm, D.L. Intravesical bacillus Calmette-Guerin reduces the risk of progression in patients with superficial bladder cancer: A meta-analysis of the published results of randomized clinical trials. J. Urol. 2002, 168, 1964-1970. [CrossRef]

57. Shelley, M.; Court, J.B.; Kynaston, H.; Wilt, T.J.; Fish, R.; Mason, M. Intravesical Bacillus Calmette-Guérin in Ta and T1 bladder cancer. Cochrane Database Syst. Rev. 2000. [CrossRef] [PubMed]

58. Shiota, M.; Kiyoshima, K.; Yokomizo, A.; Takeuchi, A.; Kashiwagi, E.; Dejima, T.; Takahashi, R.; Inokuchi, J.; Tatsugami, K.; Eto, M. Suppressed recurrent bladder cancer after androgen suppression with androgen deprivation therapy or 5a-reductase inhibitor. J. Urol. 2017, 197, 308-313. [CrossRef]

59. Kourbanhoussen, K.; McMartin, C.; Lodde, M.; Zlotta, A.; Bryan, R.T.; Toren, P. Switching cancers: A systematic review assessing the role of androgen suppressive therapy in bladder cancer. Eur. Urol. Focus 2020. Epub ahead of print. [CrossRef] [PubMed]

60. Morales, E.E.; Grill, S.; Svatek, R.S.; Kaushik, D.; Thompson, I.M.; Ankerst, D.P.; Liss, M.A. Finasteride Reduces Risk of Bladder Cancer in a Large Prospective Screening Study. Eur. Urol. 2016, 69, 407-410. [CrossRef]

61. Chen, C.C.; Huang, C.P.; Tsai, Y.T.; Hseih, T.F.; Shyr, C.R. The genomic alterations of 5a-reductases and their inhibitor Finasteride's effect in bladder cancer. Anticancer Res. 2017, 37, 6893-6898.

62. Wang, C.S.; Li, C.C.; Juan, Y.S.; Wu, W.J.; Lee, H.Y. 5a-reductase inhibitors impact prognosis of urothelial carcinoma. BMC Cancer 2020, 20, 872. [CrossRef]

63. Santella, C.; Rouette, J.; Brundage, M.D.; Filion, K.B.; Azoulay, L. Androgen deprivation therapy for prostate cancer and the risk of bladder cancer: A systematic review of observational studies. Urol. Oncol. 2020, 38, 816-825. [CrossRef] [PubMed]

64. Toren, P.; Brisson, H.; Simonyan, D.; Hovington, H.; Lacombe, L.; Bergeron, A.; Fradet, Y. Androgen receptor and immune cell PD-L1 expression in bladder tumors predicts disease recurrence and survival. World J. Urol. 2021, 39, 1549-1558. [CrossRef] [PubMed]

65. Hsu, J.W.; Hsu, I.; Xu, D.; Miyamoto, H.; Liang, L.; Wu, X.R.; Shyr, C.R.; Chang, C. Decreased tumorigenesis and mortality from bladder cancer in mice lacking urothelial androgen receptor. Am. J. Pathol. 2013, 182, 1811-1820. [CrossRef]

66. Mir, C.; Shariat, S.F.; van der Kwast, T.H.; Ashfaq, R.; Lotan, Y.; Evans, A.; Skeldon, S.; Hanna, S.; Vajpeyi, R.; Kuk, C.; et al. Loss of androgen receptor expression is not associated with pathological stage, grade, gender or outcome in bladder cancer: A large multi-institutional study. BJU Int. 2011, 108, 24-30. [CrossRef] [PubMed] 
67. Kashiwagi, E.; Ide, H.; Inoue, S.; Kawahara, T.; Zheng, Y.; Reis, L.O.; Baras, A.S.; Miyamoto, H. Androgen receptor activity modulates responses to cisplatin treatment in bladder cancer. Oncotarget 2016, 7, 49169-49179. [CrossRef]

68. Tyagi, A.; Chandrasekaran, B.; Kolluru, V.; Rai, S.; Jordan, A.C.; Houda, A.; Messer, J.; Ankem, M.; Damodaran, C.; Haddad, A. Combination of androgen receptor inhibitor and cisplatin, an effective treatment strategy for urothelial carcinoma of the bladder. Urol. Oncol. 2019, 37, 492-502. [CrossRef]

69. Jiang, G.; Teramoto, Y.; Goto, T.; Mizushima, T.; Inoue, S.; Ide, H.; Nagata, Y.; Kashiwagi, E.; Baras, A.S.; Netto, G.J.; et al. Identification of BXDC2 as a key downstream effector of the androgen receptor in modulating cisplatin sensitivity in bladder cancer. Cancers 2021, 13, 975. [CrossRef]

70. Koeken, V.A.; de Bree, L.C.J.; Mourits, V.P.; Moorlag, S.J.; Walk, J.; Cirovic, B.; Arts, R.J.; Jaeger, M.; Dijkstra, H.; Lemmers, H.; et al. BCG vaccination in humans inhibits systemic inflammation in a sex-dependent manner. J. Clin. Investig. 2020, 130, 5591-5602. [CrossRef]

71. Mizushima, T.; Jiang, G.; Kawahara, T.; Li, P.; Han, B.; Inoue, S.; Ide, H.; Kato, I.; Jalalizadeh, M.; Miyagi, E.; et al. Androgen receptor signaling reduces the efficacy of Bacillus Calmette-Guerin therapy for bladder cancer via modulating Rab27b-induced exocytosis. Mol. Cancer Ther. 2020, 19, 1930-1942. [CrossRef] [PubMed]

72. Shang, Z.; Li, Y.; Zhang, M.; Tian, J.; Han, R.; Shyr, C.R.; Messing, E.; Yeh, S.; Niu, Y.; Chang, C. Antiandrogen therapy with hydroxyflutamide or androgen receptor degradation enhancer ASC-J9 enhances BCG efficacy to better suppress bladder cancer progression. Mol. Cancer Ther. 2015, 14, 2586-2594. [CrossRef]

73. Grajales, V.; Bandari, J.; Hale, N.E.; Yabes, J.G.; Turner, R.M.; Fam, M.M., 2nd; Sabik, L.M.; Gingrich, J.R.; Davies, B.J.; Jacobs, B.L. Associations between female sex and treatment patterns and outcomes for muscle-invasive bladder cancer. Urology 2020, 151, 169-175. [CrossRef]

74. Mancini, M.; Righetto, M.; Baggio, G. Spotlight on gender-specific disparities in bladder cancer. Urologia 2020, 87, 103-114. [CrossRef]

75. Chamie, K.; Litwin, M.S.; Bassett, J.C.; Daskivich, T.J.; Lai, J.; Hanley, J.M.; Konety, B.R.; Saigal, C.S. Urologic Diseases in America P: Recurrence of high-risk bladder cancer: A population-based analysis. Cancer 2013, 119, 3219-3227. [CrossRef] [PubMed]

76. Kimura, S.; Iwata, T.; Abufaraj, M.; Janisch, F.; D’Andrea, D.; Moschini, M.; Al-Rawashdeh, B.; Fajkovic, H.; Seebacher, V.; Egawa, S.; et al. Impact of gender on chemotherapeutic response and oncologic outcomes in patients treated with radical cystectomy and perioperative chemotherapy for bladder cancer: A systematic review and meta-analysis. Clin. Genitourin. Cancer 2020, 18, 78-87. [CrossRef] [PubMed]

77. Hurst, C.D.; Alder, O.; Platt, F.M.; Droop, A.; Stead, L.F.; Burns, J.E.; Burghel, G.J.; Jain, S.; Klimczak, L.J.; Lindsay, H.; et al. Genomic subtypes of non-invasive bladder cancer with distinct metabolic profile and gemale hender bias in KDM6A mutation frequency. Cancer Cell 2017, 32, 701-715.e707. [CrossRef] [PubMed]

78. Fernandez-Gomez, J.; Solsona, E.; Unda, M.; Martinez-Pineiro, L.; Gonzalez, M.; Hernandez, R.; Madero, R.; Ojea, A.; Pertusa, C.; Rodriguez-Molina, J.; et al. Prognostic factors in patients with non-muscle-invasive bladder cancer treated with bacillus Calmette-Guerin: Multivariate analysis of data from four randomized CUETO trials. Eur. Urol. 2008, 53, 992-1001. [CrossRef] [PubMed]

79. Ainbender, E.; Weisinger, R.B.; Hevizy, M.; Hodes, H.L. Difference in the immunoglobulin class of polioantibody in the serum of men and women. J. Immunol. 1968, 101, 92-98.

80. Furman, D.; Hejblum, B.P.; Simon, N.; Jojic, V.; Dekker, C.L.; Thiebaut, R.; Tibshirani, R.J.; Davis, M.M. Systems analysis of sex differences reveals an immunosuppressive role for testosterone in the response to influenza vaccination. Proc. Natl. Acad. Sci. USA 2014, 111, 869-874. [CrossRef]

81. Klein, S.L.; Jedlicka, A.; Pekosz, A. The Xs and Y of immune responses to viral vaccines. Lancet Infect. Dis. 2010, 10, 338-349. [CrossRef]

82. Klein, S.L.; Marriott, I.; Fish, E.N. Sex-based differences in immune function and responses to vaccination. Trans. R. Soc. Trop. Med. Hyg. 2015, 109, 9-15. [CrossRef]

83. Trigunaite, A.; Dimo, J.; Jorgensen, T.N. Suppressive effects of androgens on the immune system. Cell Immunol. 2015, 294, 87-94. [CrossRef] [PubMed]

84. Gabriel, G.; Arck, P.C. Sex, immunity and influenza. J. Infect. Dis. 2014, 209 (Suppl. S3), S93-S99. [CrossRef] [PubMed]

85. De Jong, J.J.; Boormans, J.L.; van Rhijn, B.W.G.; Seiler, R.; Boorjian, S.A.; Konety, B.; Bivalacqua, T.J.; Wheeler, T.; Svatek, R.S.; Douglas, J.; et al. Distribution of molecular subtypes in muscle-invasive bladder cancer is driven by sex-specific differences. Eur. Urol. Oncol. 2020, 3, 420-423. [CrossRef] [PubMed]

86. Sottnik, J.L.; Vanderlinden, L.A.; Joshi, M.; Chauca-Diaz, A.; Owens, C.; Hansel, D.E.; Sempeck, C.; Ghosh, D.; Theodorescu, D. Androgen receptor regulates CD44 expression in bladder cancer. Cancer Res. 2021, 81, 2833-2846. [CrossRef]

87. Wu, C.T.; Lin, W.Y.; Chen, W.C.; Chen, M.F. Predictive Value of CD44 in Muscle-Invasive Bladder Cancer and Its Relationship with IL-6 Signaling. Ann. Surg. Oncol. 2018, 25, 3518-3526. [CrossRef]

88. George, S.K.; Tovar-Sepulveda, V.; Shen, S.S.; Jian, W.; Zhang, Y.; Hilsenbeck, S.G.; Lerner, S.P.; Smith, C.L. Chemoprevention of BBN-induced bladder carcinogenesis by the selective estrogen receptor modulator tamoxifen. Transl. Oncol. 2013, 6, $244-255$. [CrossRef]

89. Hsu, I.; Chuang, K.L.; Slavin, S.; Da, J.; Lim, W.X.; Pang, S.T.; O’Brien, J.H.; Yeh, S. Suppression of ERb signaling via ERb knockout or antagonist protects against bladder cancer development. Carcinogenesis 2014, 35, 651-661. [CrossRef] 
90. Hsu, I.; Yeh, C.R.; Slavin, S.; Miyamoto, H.; Netto, G.J.; Tsai, Y.C.; Muyan, M.; Wu, X.R.; Messing, E.M.; Guancial, E.A.; et al. Estrogen receptor alpha prevents bladder cancer via INPP4B inhibited akt pathway in vitro and in vivo. Oncotarget 2014, 5, 7917-7935. [CrossRef]

91. Brown, M.A.; Su, M.A. An inconvenient variable: Sex hormones and their impact on T cell responses. J. Immunol. 2019, 202, 1927-1933. [CrossRef] [PubMed]

92. Jørgensen, T.N. Sex disparities in the immune response. Cell. Immunol. 2015, 294, 61-62. [CrossRef]

93. Van den Berg, C.H.; Grady, B.P.; Schinkel, J.; van de Laar, T.; Molenkamp, R.; van Houdt, R.; Coutinho, R.A.; van Baarle, D.; Prins, M. Female sex and IL28B, a synergism for spontaneous viral clearance in hepatitis C virus (HCV) seroconverters from a community-based cohort. PLoS ONE 2011, 6, e27555. [CrossRef] [PubMed]

94. Kaplan, V.; Angus, D.C.; Griffin, M.F.; Clermont, G.; Scott Watson, R.; Linde-Zwirble, W.T. Hospitalized community-acquired pneumonia in the elderly: Age- and sex-related patterns of care and outcome in the United States. Am. J. Respir. Crit. Care Med. 2002, 165, 766-772. [CrossRef]

95. Cook, M.B.; Dawsey, S.M.; Freedman, N.D.; Inskip, P.D.; Wichner, S.M.; Quraishi, S.M.; Devesa, S.S.; McGlynn, K.A. Sex disparities in cancer incidence by period and age. Cancer Epidemiol. Biomark. Prev. 2009, 18, 1174-1182. [CrossRef] [PubMed]

96. Cook, M.B.; McGlynn, K.A.; Devesa, S.S.; Freedman, N.D.; Anderson, W.F. Sex disparities in cancer mortality and survival. Cancer Epidemiol. Biomark. Prev. 2011, 20, 1629-1637. [CrossRef] [PubMed]

97. Edgren, G.; Liang, L.; Adami, H.-O.; Chang, E.T. Enigmatic sex disparities in cancer incidence. Eur. J. Epidemiol. 2012, 27, 187-196. [CrossRef] [PubMed]

98. Wang, J.P.; Zhang, L.; Madera, R.F.; Woda, M.; Libraty, D.H. Plasmacytoid dendritic cell interferon- $\alpha$ production to R-848 stimulation is decreased in male infants. BMC Immunol. 2012, 13, 35. [CrossRef] [PubMed]

99. Roth, A.; Sodemann, M.; Jensen, H.; Poulsen, A.; Gustafson, P.; Weise, C.; Gomes, J.; Djana, Q.; Jakobsen, M.; Garly, M.L.; et al. Tuberculin reaction, BCG scar, and lower female mortality. Epidemiology 2006, 17, 562-568. [CrossRef]

100. Leposavic, G.; Perisic, M.; Kosec, D.; Arsenovic-Ranin, N.; Radojevic, K.; Stojic-Vukanic, Z.; Pilipovic, I. Neonatal testosterone imprinting affects thymus development and leads to phenotypic rejuvenation and masculinization of the peripheral blood T-cell compartment in adult female rats. Brain Behav. Immun. 2009, 23, 294-304. [CrossRef]

101. Williamson, E.J.; Walker, A.J.; Bhaskaran, K.; Bacon, S.; Bates, C.; Morton, C.E.; Curtis, H.J.; Mehrkar, A.; Evans, D.; Inglesby, P.; et al. Factors associated with COVID-19-related death using OpenSAFELY. Nature 2020, 584, 430-436. [CrossRef]

102. Chakravarty, D.; Nair, S.S.; Hammouda, N.; Ratnani, P.; Gharib, Y.; Wagaskar, V.; Mohamed, N.; Lundon, D.; Dovey, Z.; Kyprianou, N.; et al. Sex differences in SARS-CoV-2 infection rates and the potential link to prostate cancer. Commun. Biol. 2020, 3, 374. [CrossRef] [PubMed]

103. Igarashi, H.; Kouro, T.; Yokota, T.; Comp, P.C.; Kincade, P.W. Age and stage dependency of estrogen receptor expression by lymphocyte precursors. Proc. Natl. Acad. Sci. USA 2001, 98, 15131-15136. [CrossRef]

104. Mantalaris, A.; Panoskaltsis, N.; Sakai, Y.; Bourne, P.; Chang, C.; Messing, E.M.; Wu, J.H. Localization of androgen receptor expression in human bone marrow. J. Pathol. 2001, 193, 361-366. [CrossRef]

105. Dumitru, C.A.; Moses, K.; Trellakis, S.; Lang, S.; Brandau, S. Neutrophils and granulocytic myeloid-derived suppressor cells: Immunophenotyping, cell biology and clinical relevance in human oncology. Cancer Immunol. Immunother. 2012, 61, 1155-1167. [CrossRef]

106. Gabrilovich, D.I.; Nagaraj, S. Myeloid-derived suppressor cells as regulators of the immune system. Nat. Rev. Immunol. 2009, 9, 162-174. [CrossRef]

107. Thorsson, V.; Gibbs, D.L.; Brown, S.D.; Wolf, D.; Bortone, D.S.; Ou Yang, T.H.; Porta-Pardo, E.; Gao, G.F.; Plaisier, C.L.; Eddy, J.A.; et al. The immune landscape of cancer. Immunity 2018, 48, 812-830e814. [CrossRef] [PubMed]

108. Mosser, D.M.; Edwards, J.P. Exploring the full spectrum of macrophage activation. Nat. Rev. Immunol. 2008, 8, 958-969. [CrossRef] [PubMed]

109. Banchereau, J.; Steinman, R.M. Dendritic cells and the control of immunity. Nature 1998, 392, 245-252. [CrossRef]

110. Mortier, E.; Advincula, R.; Kim, L.; Chmura, S.; Barrera, J.; Reizis, B.; Malynn, B.A.; Ma, A. Macrophage- and dendritic-cell-derived interleukin-15 receptor alpha supports homeostasis of distinct CD8+ T cell subsets. Immunity 2009, 31, 811-822. [CrossRef]

111. Askenase, M.H.; Han, S.J.; Byrd, A.L.; Morais da Fonseca, D.; Bouladoux, N.; Wilhelm, C.; Konkel, J.E.; Hand, T.W.; LacerdaQueiroz, N.; Su, X.Z.; et al. Bone-marrow-resident NK cells prime monocytes for regulatory function during infection. Immunity 2015, 42, 1130-1142. [CrossRef]

112. Wong, J.L.; Berk, E.; Edwards, R.P.; Kalinski, P. IL-18-primed helper NK cells collaborate with dendritic cells to promote recruitment of effector CD8+ T cells to the tumor microenvironment. Cancer Res. 2013, 73, 4653-4662. [CrossRef]

113. Goldszmid, R.S.; Caspar, P.; Rivollier, A.; White, S.; Dzutsev, A.; Hieny, S.; Kelsall, B.; Trinchieri, G.; Sher, A. NK cell-derived interferon-g orchestrates cellular dynamics and the differentiation of monocytes into dendritic cells at the site of infection. Immunity 2012, 36, 1047-1059. [CrossRef]

114. Mattiola, I.; Pesant, M.; Tentorio, P.F.; Molgora, M.; Marcenaro, E.; Lugli, E.; Locati, M.; Mavilio, D. Priming of human resting NK cells by autologous M1 macrophages via the engagement of IL-1b, IFN-b, and IL-15 pathways. J. Immunol. 2015, 195, 2818-2828. [CrossRef]

115. Hanna, R.N.; Cekic, C.; Sag, D.; Tacke, R.; Thomas, G.D.; Nowyhed, H.; Herrley, E.; Rasquinha, N.; McArdle, S.; Wu, R.; et al. Patrolling monocytes control tumor metastasis to the lung. Science 2015, 350, 985-990. [CrossRef] [PubMed] 
116. Tchkonia, T.; Zhu, Y.; van Deursen, J.; Campisi, J.; Kirkland, J.L. Cellular senescence and the senescent secretory phenotype: Therapeutic opportunities. J. Clin. Investig. 2013, 123, 966-972. [CrossRef]

117. Senovilla, L.; Galluzzi, L.; Zitvogel, L.; Kroemer, G. Immunosurveillance as a regulator of tissue homeostasis. Trends Immunol. 2013, 34, 471-481. [CrossRef] [PubMed]

118. Stefater, J.A., 3rd; Ren, S.; Lang, R.A.; Duffield, J.S. Metchnikoff's policemen: Macrophages in development, homeostasis and regeneration. Trends Mol. Med. 2011, 17, 743-752. [CrossRef]

119. Fadok, V.A.; Voelker, D.R.; Campbell, P.A.; Cohen, J.J.; Bratton, D.L.; Henson, P.M. Exposure of phosphatidylserine on the surface of apoptotic lymphocytes triggers specific recognition and removal by macrophages. J. Immunol. 1992, 148, $2207-2216$.

120. Savill, J.; Hogg, N.; Ren, Y.; Haslett, C. Thrombospondin cooperates with CD36 and the vitronectin receptor in macrophage recognition of neutrophils undergoing apoptosis. J. Clin. Investig. 1992, 90, 1513-1522. [CrossRef]

121. Ramirez, M.C.; Sigal, L.J. Macrophages and dendritic cells use the cytosolic pathway to rapidly cross-present antigen from live, vaccinia-infected cells. J. Immunol. 2002, 169, 6733-6742. [CrossRef] [PubMed]

122. Consiglio, C.R.; Gollnick, S.O. Androgen receptor signaling positively regulates monocytic development. Front. Immunol. 2020 11, 519383. [CrossRef] [PubMed]

123. Rettew, J.A.; Huet-Hudson, Y.M.; Marriott, I. Testosterone reduces macrophage expression in the mouse of toll-like receptor 4, a trigger for inflammation and innate immunity. Biol. Reprod. 2008, 78, 432-437. [CrossRef] [PubMed]

124. Ashcroft, G.S.; Mills, S.J. Androgen receptor-mediated inhibition of cutaneous wound healing. J. Clin. Investig. 2002, 110, 615-624. [CrossRef] [PubMed]

125. Lai, J.J.; Lai, K.P.; Chuang, K.H.; Chang, P.; Yu, I.C.; Lin, W.J.; Chang, C. Monocyte/macrophage androgen receptor suppresses cutaneous wound healing in mice by enhancing local TNF-a expression. J. Clin. Investig. 2009, 119, 3739-3751. [CrossRef]

126. Corcoran, M.P.; Meydani, M.; Lichtenstein, A.H.; Schaefer, E.J.; Dillard, A.; Lamon-Fava, S. Sex hormone modulation of proinflammatory cytokine and C-reactive protein expression in macrophages from older men and postmenopausal women. $J$. Endocrinol. 2010, 206, 217-224. [CrossRef] [PubMed]

127. Male, D.; Brostoff, J.; Roth, D.; Roitt, I. Immunology, 8th ed.; Elsevier: Amsterdam, The Netherlands, 2013.

128. Lai, J.J.; Lai, K.P.; Zeng, W.; Chuang, K.H.; Altuwaijri, S.; Chang, C. Androgen receptor influences on body defense system via modulation of innate and adaptive immune systems: Lessons from conditional AR knockout mice. Am. J. Pathol. 2012, 181, 1504-1512. [CrossRef]

129. McDonnell, N.D.; Livingston, R.B. Severe reversible neutropenia following treatment of prostate cancer with flutamide. J. Urol. 1994, 151, 1353-1354. [CrossRef]

130. Inamdar Doddamani, L.S.; Jayamma, Y. Acceleration of neutrophil precursors' maturation and immunostimulation of CD3+, CD4+ lymphocytes by stanozolol in mice. J. Steroid Biochem. Mol. Biol. 2012, 129, 172-178. [CrossRef]

131. Marin, D.P.; Bolin, A.P.; dos Santos Rde, C.; Curi, R.; Otton, R. Testosterone suppresses oxidative stress in human neutrophils. Cell Biochem. Funct. 2010, 28, 394-402. [CrossRef]

132. Scalerandi, M.V.; Peinetti, N.; Leimgruber, C.; Cuello Rubio, M.M.; Nicola, J.P.; Menezes, G.B.; Maldonado, C.A.; Quintar, A.A. Inefficient N2-like neutrophils are promoted by androgens during infection. Front. Immunol. 2018, 9, 1980. [CrossRef]

133. Guo, Z.; Tilburgs, T.; Wong, B.; Strominger, J.L. Dysfunction of dendritic cells in aged C57BL/6 mice leads to failure of natural killer cell activation and of tumor eradication. Proc. Natl. Acad. Sci. USA 2014, 111, 14199-14204. [CrossRef] [PubMed]

134. Humann, J.; Lenz, L.L. Activation of naive NK cells in response to Listeria monocytogenes requires IL-18 and contact with infected dendritic cells. J. Immunol. 2010, 184, 5172-5178. [CrossRef]

135. Mortier, E.; Woo, T.; Advincula, R.; Gozalo, S.; Ma, A. IL-15Ra chaperones IL-15 to stable dendritic cell membrane complexes that activate NK cells via trans presentation. J. Exp. Med. 2008, 205, 1213-1225. [CrossRef] [PubMed]

136. Stonier, S.W.; Schluns, K.S. Trans-presentation: A novel mechanism regulating IL-15 delivery and responses. Immunol. Lett. 2010, 127, 85-92. [CrossRef]

137. Castillo, E.F.; Stonier, S.W.; Frasca, L.; Schluns, K.S. Dendritic cells support the in vivo development and maintenance of NK cells via IL-15 trans-presentation. J. Immunol. 2009, 183, 4948-4956. [CrossRef]

138. Gerosa, F.; Gobbi, A.; Zorzi, P.; Burg, S.; Briere, F.; Carra, G.; Trinchieri, G. The reciprocal interaction of NK cells with plasmacytoid or myeloid dendritic cells profoundly affects innate resistance functions. J. Immunol. 2005, 174, 727-734. [CrossRef]

139. Paharkova-Vatchkova, V.; Maldonado, R.; Kovats, S.; Offner, H. Estrogen preferentially promotes the differentiation of CD11c ${ }^{+}$ CD11b intermediate dendritic cells from bone marrow precursors. J. Immunol. 2004, 172, 1426-1436. [CrossRef]

140. Lin, A.A.; Wojciechowski, S.E.; Hildeman, D.A. Androgens suppress antigen-specific T cell responses and IFN-g production during intracranial LCMV infection. J. Neuroimmunol. 2010, 226, 8-19. [CrossRef]

141. Germain, R.N. MHC-dependent antigen processing and peptide presentation: Providing ligands for T lymphocyte activation. Cell 1994, 76, 287-299. [CrossRef]

142. Chen, C.; Gault, A.; Shen, L.; Nabavi, N. Molecular cloning and expression of early T cell costimulatory molecule-1 and its characterization as B7-2 molecule. J. Immunol. 1994, 152, 4929-4936. [PubMed]

143. Koh, Y.T.; Gray, A.; Higgins, S.A.; Hubby, B.; Kast, W.M. Androgen ablation augments prostate cancer vaccine immunogenicity only when applied after immunization. Prostate 2009, 69, 571-584. [CrossRef]

144. Caligiuri, M.A. Human natural killer cells. Blood 2008, 112, 461-469. [CrossRef] [PubMed]

145. Trinchieri, G. Biology of natural killer cells. Adv. Immunol. 1989, 47, 187-376. 
146. Morvan, M.G.; Lanier, L.L. NK cells and cancer: You can teach innate cells new tricks. Nat. Rev. Cancer 2016, 16, 7-19. [CrossRef]

147. Chockley, P.J.; Chen, J.; Chen, G.; Beer, D.G.; Standiford, T.J.; Keshamouni, V.G. Epithelial-mesenchymal transition leads to NK cell-mediated metastasis-specific immunosurveillance in lung cancer. J. Clin. Investig. 2018, 128, 1384-1396. [CrossRef]

148. Guerra, N.; Tan, Y.X.; Joncker, N.T.; Choy, A.; Gallardo, F.; Xiong, N.; Knoblaugh, S.; Cado, D.; Greenberg, N.M.; Raulet, D.H. NKG2D-deficient mice are defective in tumor surveillance in models of spontaneous malignancy. Immunity 2008, 28, 571-580. [CrossRef]

149. Kim, S.; Iizuka, K.; Aguila, H.L.; Weissman, I.L.; Yokoyama, W.M. In vivo natural killer cell activities revealed by natural killer cell-deficient mice. Proc. Natl. Acad. Sci. USA 2000, 97, 2731-2736. [CrossRef] [PubMed]

150. Tai, L.H.; de Souza, C.T.; Belanger, S.; Ly, L.; Alkayyal, A.A.; Zhang, J.; Rintoul, J.L.; Ananth, A.A.; Lam, T.; Breitbach, C.J.; et al. Preventing postoperative metastatic disease by inhibiting surgery-induced dysfunction in natural killer cells. Cancer Res. 2012, 73, 97-107. [CrossRef] [PubMed]

151. Harty, J.T.; Tvinnereim, A.R.; White, D.W. CD8+ T cell effector mechanisms in resistance to infection. Annu. Rev. Immunol. 2000, 18, 275-308. [CrossRef] [PubMed]

152. Long, E.O. Negative signaling by inhibitory receptors: The NK cell paradigm. Immunol. Rev. 2008, 224, 70-84. [CrossRef]

153. Yu, J.; Heller, G.; Chewning, J.; Kim, S.; Yokoyama, W.M.; Hsu, K.C. Hierarchy of the human natural killer cell response is determined by class and quantity of Inhibitory receptors for self-HLA-B and HLA-C ligands. J. Immunol. 2007, 179, 5977-5989. [CrossRef]

154. Raulet, D.H. Roles of the NKG2D immunoreceptor and its ligands. Nat. Rev. Immunol. 2003, 3, 781-790. [CrossRef] [PubMed]

155. Page, S.T.; Plymate, S.R.; Bremner, W.J.; Matsumoto, A.M.; Hess, D.L.; Lin, D.W.; Amory, J.K.; Nelson, P.S.; Wu, J.D. Effect of medical castration on CD4+ CD25+ T cells, CD8+ T cell IFN-gamma expression, and NK cells: A physiological role for testosterone and/or its metabolites. Am. J. Physiol. Endocrinol. Metab. 2006, 290, E856-E863. [CrossRef] [PubMed]

156. Al-Attar, A.; Presnell, S.R.; Peterson, C.A.; Thomas, D.T.; Lutz, C.T. The effect of sex on immune cells in healthy aging: Elderly women have more robust natural killer lymphocytes than do elderly men. Mech. Ageing Dev. 2016, 156, 25-33. [CrossRef]

157. Crotty, S. Follicular helper CD4 T cells (TFH). Annu. Rev. Immunol. 2011, 29, 621-663. [CrossRef] [PubMed]

158. Forthal, D.N. Functions of antibodies. Microbiol. Spectr. 2014, 2, 1-17. [CrossRef]

159. Viselli, S.M.; Reese, K.R.; Fan, J.; Kovacs, W.J.; Olsen, N.J. Androgens alter B cell development in normal male mice. Cell Immunol. 1997, 182, 99-104. [CrossRef] [PubMed]

160. Fitzpatrick, F.; Lepault, F.; Homo-Delarche, F.; Bach, J.-F.; Dardenne, M. Influence of castration, alone or combined with thymectomy, on the development of iabetes in the nonobese diabetic mouse. Endocrinology 1991, 129, 1382-1390. [CrossRef] [PubMed]

161. Liva, S.M.; Voskuhl, R.R. Testosterone acts directly on CD4+ T lymphocytes to increase IL-10 production. J. Immunol. 2001, 167, 2060-2067. [CrossRef] [PubMed]

162. Ellis, T.M.; Moser, M.T.; Le, P.T.; Flanigan, R.C.; Kwon, E.D. Alterations in peripheral B cells and B cell progenitors following androgen ablation in mice. Int. Immunol. 2001, 13, 553-558. [CrossRef] [PubMed]

163. Smithson, G.; Couse, J.F.; Lubahn, D.B.; Korach, K.S.; Kincade, P.W. The role of estrogen receptors and androgen receptors in sex steroid regulation of B lymphopoiesis. J. Immunol. 1998, 161, 27-34.

164. Olsen, N.J.; Gu, X.; Kovacs, W.J. Bone marrow stromal cells mediate androgenic suppression of B lymphocyte development. J. Clin. Investig. 2001, 108, 1697-1704. [CrossRef]

165. Altuwaijri, S.; Chuang, K.-H.; Lai, K.-P.; Lai, J.-J.; Lin, H.-Y.; Young, F.M.; Bottaro, A.; Tsai, M.-Y.; Zeng, W.-P.; Chang, H.-C.; et al. Susceptibility to autoimmunity and B cell resistance to apoptosis in mice lacking androgen receptor in B cells. Mol. Endocrinol. 2009, 23, 444-453. [CrossRef] [PubMed]

166. Olsen, N.J.; Kovacs, W.J. Effects of androgens on T and B lymphocyte development. Immunol. Res. 2001, 23, 281-288. [CrossRef]

167. Henderson, J. On the relationship of the thymus to the sexual organs: I. The influence of castration on the thymus. J. Physiol. 1904, 31, 222-229. [CrossRef] [PubMed]

168. Dulos, G.J.; Bagchus, W.M. Androgens indirectly accelerate thymocyte apoptosis. Int. Immunopharmacol. 2001, 1, 321-328. [CrossRef]

169. Olsen, N.J.; Olson, G.; Viselli, S.M.; Gu, X.; Kovacs, W.J. Androgen receptors in thymic epithelium modulate thymus size and thymocyte development. Endocrinology 2001, 142, 1278-1283. [CrossRef] [PubMed]

170. Sutherland, J.S.; Goldberg, G.L.; Hammett, M.V.; Uldrich, A.P.; Berzins, S.P.; Heng, T.S.; Blazar, B.R.; Millar, J.L.; Malin, M.A.; Chidgey, A.P.; et al. Activation of thymic regeneration in mice and humans following androgen blockade. J. Immunol. 2005, 175, 2741-2753. [CrossRef]

171. Velardi, E.; Tsai, J.J.; Holland, A.M.; Wertheimer, T.; Yu, V.W.; Zakrzewski, J.L.; Tuckett, A.Z.; Singer, N.V.; West, M.L.; Smith, O.M.; et al. Sex steroid blockade enhances thymopoiesis by modulating Notch signaling. J. Exp. Med. 2014, 211, 2341-2349. [CrossRef]

172. Kissick, H.T.; Sanda, M.G.; Dunn, L.K.; Pellegrini, K.L.; On, S.T.; Noel, J.K.; Arredouani, M.S. Androgens alter T-cell immunity by inhibiting T-helper 1 differentiation. Proc. Natl. Acad. Sci. USA 2014, 111, 9887-9892. [CrossRef] [PubMed]

173. Viselli, S.M.; Olsen, N.J.; Shults, K.; Steizer, G.; Kovacs, W.J. Immunochemical and flow cytometric analysis of androgen receptor expression in thymocytes. Mol. Cell Endocrinol. 1995, 109, 19-26. [CrossRef]

174. Walecki, M.; Eisel, F.; Klug, J.; Baal, N.; Paradowska-Dogan, A.; Wahle, E.; Hackstein, H.; Meinhardt, A.; Fijak, M. Androgen receptor modulates Foxp3 expression in CD4+CD25+Foxp3+ regulatory T-cells. Mol. Biol. Cell 2015, 26, 2845-2857. [CrossRef] 
175. Constant, S.L.; Bottomly, K. Induction of Th1 and Th2 CD4+ T cell responses: The alternative approaches. Annu. Rev. Immunol. 1997, 15, 297-322. [CrossRef]

176. Hepworth, M.R.; Hardman, M.J.; Grencis, R.K. The role of sex hormones in the development of Th2 immunity in a gender-biased model of Trichuris muris infection. Eur. J. Immunol. 2010, 40, 406-416. [CrossRef]

177. Pestka, S.; Krause, C.D.; Sarkar, D.; Walter, M.R.; Shi, Y.; Fisher, P.B. Interleukin-10 and related cytokines and receptors. Annu. Rev. Immunol. 2004, 22, 929-979. [CrossRef] [PubMed]

178. Bebo, B.F.; Schuster, J.C.; Vandenbark, A.A.; Offner, H. Androgens alter the cytokine profile and reduce encephalitogenicity of myelin-reactive T cells. J. Immunol. 1999, 162, 35-40. [PubMed]

179. Russi, A.E.; Ebel, M.E.; Yang, Y.; Brown, M.A. Male-specific IL-33 expression regulates sex-dimorphic EAE susceptibility. Proc. Natl. Acad. Sci. USA 2018, 115, E1520-E1529. [CrossRef]

180. Russi, A.E.; Walker-Caulfield, M.E.; Ebel, M.E.; Brown, M.A. Cutting edge: C-Kit signaling differentially regulates type 2 innate lymphoid cell accumulation and susceptibility to central nervous system demyelination in male and female SJL mice. J. Immunol. 2015, 194, 5609-5613. [CrossRef]

181. Miller, A.M. Role of IL-33 in inflammation and disease. J. Inflamm. 2011, 8, 22. [CrossRef]

182. Shimizu, J.; Yamazaki, S.; Sakaguchi, S. Induction of tumor immunity by removing CD25+CD4+ T cells: A common basis between tumor immunity and autoimmunity. J. Immunol. 1999, 163, 5211-5218.

183. Nelson, B.H. IL-2, regulatory T cells, and tolerance. J. Immunol. 2004, 172, 3983-3988. [CrossRef]

184. Kerdiles, Y.; Ugolini, S.; Vivier, E. T cell regulation of natural killer cells. J. Exp. Med. 2013, 210, 1065-1068. [CrossRef] [PubMed]

185. Josefowicz, S.Z.; Lu, L.F.; Rudensky, A.Y. Regulatory T cells: Mechanisms of differentiation and function. Annu. Rev. Immunol. 2012, 30, 531-564. [CrossRef] [PubMed]

186. Rudensky, A.Y.; Gavin, M.; Zheng, Y. FOXP3 and NFAT: Partners in tolerance. Cell 2006, 126, 253-256. [CrossRef]

187. Maduro, C.; de Hoon, B.; Gribnau, J. Fitting the puzzle pieces: The bigger picture of XCI. Trends Biochem. Sci. 2016, 41, 138-147. [CrossRef]

188. Carrel, L.; Willard, H.F. X-inactivation profile reveals extensive variability in X-linked gene expression in females. Nature 2005, 434, 400-404. [CrossRef]

189. Balaton, B.P.; Cotton, A.M.; Brown, C.J. Derivation of consensus inactivation status for X-linked genes from genome-wide studies. Biol. Sex. Differ. 2015, 6, 35. [CrossRef]

190. Garieri, M.; Stamoulis, G.; Blanc, X.; Falconnet, E.; Ribaux, P.; Borel, C.; Santoni, F.; Antonarakis, S.E. Extensive cellular heterogeneity of $\mathrm{X}$ inactivation revealed by single-cell allele-specific expression in human fibroblasts. Proc. Natl. Acad. Sci. USA 2018, 115, 13015-13020. [CrossRef]

191. Zito, A.; Davies, M.N.; Tsai, P.C.; Roberts, S.; Andres-Ejarque, R.; Nardone, S.; Bell, J.T.; Wong, C.C.Y.; Small, K.S. Heritability of skewed $X$-inactivation in female twins is tissue-specific and associated with age. Nat. Commun. 2019, 10, 5339. [CrossRef]

192. Ji, J.; Zöller, B.; Sundquist, J.; Sundquist, K. Risk of solid tumors and hematological malignancy in persons with Turner and Klinefelter syndromes: A national cohort study. Int. J. Cancer 2016, 139, 754-758. [CrossRef]

193. Schoemaker, M.J.; Swerdlow, A.J.; Higgins, C.D.; Wright, A.F.; Jacobs, P.A.; Group UKCC. Cancer incidence in women with Turner syndrome in Great Britain: A national cohort study. Lancet Oncol. 2008, 9, 239-246. [CrossRef]

194. Souyris, M.; Cenac, C.; Azar, P.; Daviaud, D.; Canivet, A.; Grunenwald, S.; Pienkowski, C.; Chaumeil, J.; Mejia, J.E.; Guery, J.C. TLR7 escapes X chromosome inactivation in immune cells. Sci. Immunol. 2018, 3. [CrossRef]

195. De Vries, G.J.; Rissman, E.F.; Simerly, R.B.; Yang, L.Y.; Scordalakes, E.M.; Auger, C.J.; Swain, A.; Lovell-Badge, R.; Burgoyne, P.S.; Arnold, A.P. A model system for study of sex chromosome effects on sexually dimorphic neural and behavioral traits. J. Neurosci. 2002, 22, 9005-9014. [CrossRef] [PubMed]

196. Kaneko, S.; Li, X. X chromosome protects against bladder cancer in females via a KDM6A-dependent epigenetic mechanism. Sci. Adv. 2018, 4, eaar5598. [CrossRef]

197. Lahn, B.T.; Page, D.C. Functional coherence of the human Y chromosome. Science 1997, 278, 675-680. [CrossRef] [PubMed]

198. Greenfield, A.; Carrel, L.; Pennisi, D.; Philippe, C.; Quaderi, N.; Siggers, P.; Steiner, K.; Tam, P.P.; Monaco, A.P.; Willard, H.F.; et al. The UTX gene escapes X inactivation in mice and humans. Hum. Mol. Genet. 1998, 7, 737-742. [CrossRef] [PubMed]

199. Ler, L.D.; Ghosh, S.; Chai, X.; Thike, A.A.; Heng, H.L.; Siew, E.Y.; Dey, S.; Koh, L.K.; Lim, J.Q.; Lim, W.K.; et al. Loss of tumor suppressor KDM6A amplifies PRC2-regulated transcriptional repression in bladder cancer and can be targeted through inhibition of EZH2. Sci. Transl. Med. 2017, 9. [CrossRef] [PubMed]

200. Ezponda, T.; Dupere-Richer, D.; Will, C.M.; Small, E.C.; Varghese, N.; Patel, T.; Nabet, B.; Popovic, R.; Oyer, J.; Bulic, M.; et al. UTX/KDM6A loss rnhances the malignant phenotype of multiple myeloma and densitizes vells to EZH2 inhibition. Cell Rep. 2017, 21, 628-640. [CrossRef]

201. Garczyk, S.; Ortiz-Bruchle, N.; Schneider, U.; Lurje, I.; Guricova, K.; Gaisa, N.T.; Lorsy, E.; Lindemann-Docter, K.; Heidenreich, A.; Knuchel, R. Next-generation sequencing reveals potential predictive biomarkers and targets of therapy for urothelial carcinoma in situ of the urinary bladder. Am. J. Pathol. 2020, 190, 323-332. [CrossRef]

202. Tricarico, R.; Nicolas, E.; Hall, M.J.; Golemis, E.A. X- and Y-linked chromatin-modifying genes as regulators of sex-specific cancer incidence and prognosis. Clin. Cancer Res. 2020, 26, 5567-5578. [CrossRef] 
203. Ramakrishnan, S.; Granger, V.; Rak, M.; Hu, Q.; Attwood, K.; Aquila, L.; Krishnan, N.; Osiecki, R.; Azabdaftari, G.; Guru, K.; et al. Inhibition of EZH2 induces NK cell-mediated differentiation and death in muscle-invasive bladder cancer. Cell Death Differ. 2019, 26, 2100-2114. [CrossRef]

204. Dunford, A.; Weinstock, D.M.; Savova, V.; Schumacher, S.E.; Cleary, J.P.; Yoda, A.; Sullivan, T.J.; Hess, J.M.; Gimelbrant, A.A.; Beroukhim, R.; et al. Tumor-suppressor genes that escape from X-inactivation contribute to cancer sex bias. Nat. Genet. 2017, 49, 10-16. [CrossRef]

205. Forsberg, L.A.; Rasi, C.; Malmqvist, N.; Davies, H.; Pasupulati, S.; Pakalapati, G.; Sandgren, J.; de Ståhl, T.D.; Zaghlool, A.; Giedraitis, V.; et al. Mosaic loss of chromosome $\mathrm{Y}$ in peripheral blood is associated with shorter survival and higher risk of cancer. Nat. Genet. 2014, 46, 624-628. [CrossRef]

206. Fadl-Elmula, I.; Gorunova, L.; Mandahl, N.; Elfving, P.; Lundgren, R.; Mitelman, F.; Heim, S. Karyotypic characterization of urinary bladder transitional cell carcinomas. Genes Chromosomes Cancer 2000, 29, 256-265. [CrossRef]

207. Ahn, J.; Kim, K.H.; Park, S.; Ahn, Y.H.; Kim, H.Y.; Yoon, H.; Lee, J.H.; Bang, D.; Lee, D.H. Target sequencing and CRISPR/Cas editing reveal simultaneous loss of UTX and UTY in urothelial bladder cancer. Oncotarget 2016, 7, 63252-63260. [CrossRef]

208. Liang, Y.; Tsoi, L.C.; Xing, X.; Beamer, M.A.; Swindell, W.R.; Sarkar, M.K.; Berthier, C.C.; Stuart, P.E.; Harms, P.W.; Nair, R.P.; et al. A gene network regulated by the transcription factor VGLL3 as a promoter of sex-biased autoimmune diseases. Nat. Immunol. 2017, 18, 152-160. [CrossRef]

209. Gambaro, K.; Quinn, M.C.; Wojnarowicz, P.M.; Arcand, S.L.; de Ladurantaye, M.; Barres, V.; Ripeau, J.S.; Killary, A.M.; Davis, E.C.; Lavoie, J.; et al. VGLL3 expression is associated with a tumor suppressor phenotype in epithelial ovarian cancer. Mol. Oncol. 2013, 7, 513-530. [CrossRef] [PubMed]

210. Zhang, L.; Li, L.; Mao, Y.; Hua, D. VGLL3 is a prognostic biomarker and correlated with clinical pathologic features and immune infiltrates in stomach adenocarcinoma. Sci. Rep. 2020, 10, 1355. [CrossRef] [PubMed]

211. Peng, Z.; Skoog, L.; Hellborg, H.; Jonstam, G.; Wingmo, I.L.; Hjalm-Eriksson, M.; Harmenberg, U.; Cedermark, G.C.; Andersson, K.; Ahrlund-Richter, L.; et al. An expression signature at diagnosis to estimate prostate cancer patients' overall survival. Prostate Cancer Prostatic Dis. 2014, 17, 81-90. [CrossRef]

212. Sabag, E.; Halperin, E.; Liron, T.; Hiram-Bab, S.; Frenkel, B.; Gabet, Y. Hormone-independent sexual dimorphism in the regulation of bone resorption by Krox20. J. Bone Miner. Res. 2019, 34, 2277-2286. [CrossRef] [PubMed]

213. Sacchi, M.; Klapan, I.; Johnson, J.T.; Whiteside, T.L. Antiproliferative effects of cytokines on squamous cell carcinoma. Arch. Otolaryngol. Head Neck Surg. 1991, 117, 321-326. [CrossRef]

214. Gegenhuber, B.; Tollkuhn, J. Signatures of sex: Sex differences in gene expression in the vertebrate brain. Wiley Interdiscip. Rev. Dev. Biol. 2020, 9, e348. [CrossRef]

215. Lopes-Ramos, C.M.; Chen, C.Y.; Kuijjer, M.L.; Paulson, J.N.; Sonawane, A.R.; Fagny, M.; Platig, J.; Glass, K.; Quackenbush, J.; DeMeo, D.L. Sex differences in gene expression and regulatory networks across 29 human tissues. Cell Rep. 2020, $31,107795$. [CrossRef] [PubMed]

216. Mukherjee, N.; Ji, N.; Hurez, V.; Curiel, T.J.; Montgomery, M.O.; Braun, A.J.; Nicolas, M.; Aguilera, M.; Kaushik, D.; Liu, Q.; et al. Intratumoral CD56 $6^{\text {bright }}$ natural killer cells are associated with improved survival in bladder cancer. Oncotarget 2018, 9 , 36492-36502. [CrossRef]

217. Wu, X.; Lv, D.; Cai, C.; Zhao, Z.; Wang, M.; Chen, W.; Liu, Y. A TP53-associated immune prognostic signature for the prediction of overall survival and therapeutic responses in muscle-invasive bladder cancer. Front. Immunol. 2020, 11, 590618. [CrossRef] [PubMed]

218. Qing, L.; Gu, P.; Liu, M.; Shen, J.; Liu, X.; Guang, R.; Ke, K.; Huang, Z.; Lee, W.; Zhao, H. Extracellular matrix-related six-lncRNA signature as a novel prognostic biomarker for bladder cancer. Onco. Targets Ther. 2020, 13, 12521-12538. [CrossRef] [PubMed]

219. Wang, Y.; Ba, H.J.; Liu, Z.C.; Deng, X.B.; Zhou, M. Prognostic value of immune cell infiltration in bladder cancer: A gene expression-based study. Oncol. Lett. 2020, 20, 1677-1684. [CrossRef]

220. Zhang, Y.; Ou, D.H.; Zhuang, D.W.; Zheng, Z.F.; Lin, M.E. In silico analysis of the immune microenvironment in bladder cancer. BMC Cancer 2020, 20, 265. [CrossRef] [PubMed]

221. Ratliff, T.L.; Ritchey, J.K.; Yuan, J.J.; Andriole, G.L.; Catalona, W.J. T-cell subsets required for intravesical BCG immunotherapy for bladder cancer. J. Urol. 1993, 150, 1018-1023. [CrossRef]

222. Biot, C.; Rentsch, C.A.; Gsponer, J.R.; Birkhauser, F.D.; Jusforgues-Saklani, H.; Lemaitre, F.; Auriau, C.; Bachmann, A.; Bousso, P.; Demangel, C.; et al. Preexisting BCG-specific T cells improve intravesical immunotherapy for bladder cancer. Sci. Transl. Med. 2012, 4, lodk4:137ra172. [CrossRef]

223. Brandau, S.; Riemensberger, J.; Jacobsen, M.; Kemp, D.; Zhao, W.; Zhao, X.; Jocham, D.; Ratliff, T.L.; Bohle, A. NK cells are essential for effective BCG immunotherapy. Int. J. Cancer 2001, 92, 697-702. [CrossRef]

224. Garcia-Cuesta, E.M.; Lopez-Cobo, S.; Alvarez-Maestro, M.; Esteso, G.; Romera-Cardenas, G.; Rey, M.; Cassady-Cain, R.L.; Linares, A.; Vales-Gomez, A.; Reyburn, H.T.; et al. NKG2D is a key receptor for recognition of bladder cancer cells by IL-2-activated NK cels and BCG pomotes NK cell activation. Front. Immunol. 2015, 6, 284.

225. Ferreira-Teixeira, M.; Paiva-Oliveira, D.; Parada, B.; Alves, V.; Sousa, V.; Chijioke, O.; Munz, C.; Reis, F.; Rodrigues-Santos, P.; Gomes, C. Natural killer cell-based adoptive immunotherapy eradicates and drives differentiation of chemoresistant bladder cancer stem-like cells. BMC Med. 2016, 14, 163. [CrossRef] [PubMed] 
226. Kleinnijenhuis, J.; Quintin, J.; Preijers, F.; Joosten, L.A.; Jacobs, C.; Xavier, R.J.; van der Meer, J.W.; van Crevel, R.; Netea, M.G. BCG-induced trained immunity in NK cells: Role for non-specific protection to infection. Clin. Immunol. 2014, 155, 213-219. [CrossRef]

227. Juelke, K.; Killig, M.; Luetke-Eversloh, M.; Parente, E.; Gruen, J.; Morandi, B.; Ferlazzo, G.; Thiel, A.; Schmitt-Knosalla, I.; Romagnani, C. CD62L expression identifies a unique subset of polyfunctional CD56dim NK cells. Blood 2010, 116, $1299-1307$. [CrossRef]

228. Miller, J.S. Therapeutic applications: Natural killer cells in the clinic. Hematology 2013, 2013, 247-253. [CrossRef]

229. Caligiuri, M.A.; Murray, C.; Robertson, M.J.; Wang, E.; Cochran, K.; Cameron, C.; Schow, P.; Ross, M.E.; Klumpp, T.R.; Soiffer, R.J.; et al. Selective modulation of human natural killer cells in vivo after prolonged infusion of low dose recombinant interleukin 2 . $J$. Clin. Investig. 1993, 91, 123-132. [CrossRef]

230. Rosenberg, S.A.; Yang, J.C.; White, D.E.; Steinberg, S.M. Durability of complete responses in patients with metastatic cancer treated with high-dose interleukin-2: Identification of the antigens mediating response. Ann. Surg. 1998, 228, 307-319. [CrossRef] [PubMed]

231. Zorn, E.; Nelson, E.A.; Mohseni, M.; Porcheray, F.; Kim, H.; Litsa, D.; Bellucci, R.; Raderschall, E.; Canning, C.; Soiffer, R.J.; et al. IL-2 regulates FOXP3 expression in human $\mathrm{CD} 4{ }^{+} \mathrm{CD} 25^{+}$regulatory $\mathrm{T}$ cells through a STAT-dependent mechanism and induces the expansion of these cells in vivo. Blood 2006, 108, 1571-1579. [CrossRef]

232. Ghiringhelli, F.; Ménard, C.; Terme, M.; Flament, C.; Taieb, J.; Chaput, N.; Puig, P.E.; Novault, S.; Escudier, B.; Vivier, E.; et al. $\mathrm{CD} 4{ }^{+} \mathrm{CD} 25^{+}$regulatory $\mathrm{T}$ cells inhibit natural killer cell functions in a transforming growth factor-b-dependent manner. J. Exp. Med. 2005, 202, 1075-1085. [CrossRef]

233. Waldmann, T.A.; Dubois, S.; Tagaya, Y. Contrasting roles of IL-2 and IL-15 in the life and death of lymphocytes: Implications for immunotherapy. Immunity 2001, 14, 105-110. [CrossRef]

234. Romee, R.; Cooley, S.; Berrien-Elliott, M.M.; Westervelt, P.; Verneris, M.R.; Wagner, J.E.; Weisdorf, D.J.; Blazar, B.R.; Ustun, C.; DeFor, T.E.; et al. First-in-human phase 1 clinical study of the IL-15 superagonist complex ALT-803 to treat relapse after transplantation. Blood 2018, 131, 2515-2527. [CrossRef] [PubMed]

235. Ben Ahmed, M.; Belhadj Hmida, N.; Moes, N.; Buyse, S.; Abdeladhim, M.; Louzir, H.; Cerf-Bensussan, N. IL-15 renders conventional lymphocytes resistant to suppressive functions of regulatory $\mathrm{T}$ cells through activation of the phosphatidylinositol 3-kinase pathway. J. Immunol. 2009, 182, 6763-6770. [CrossRef] [PubMed]

236. Miller, J.S.; Soignier, Y.; Panoskaltsis-Mortari, A.; McNearney, S.A.; Yun, G.H.; Fautsch, S.K.; McKenna, D.; Le, C.; Defor, T.E.; Burns, L.J.; et al. Successful adoptive transfer and in vivo expansion of human haploidentical NK cells in patients with cancer. Blood 2005, 105, 3051-3057. [CrossRef] [PubMed]

237. Yu, Z.; Pestell, T.G.; Lisanti, M.P.; Pestell, R.G. Cancer stem cells. Int. J. Biochem. Cell Biol. 2012, 44, 2144-2151. [CrossRef] [PubMed]

238. Reya, T.; Morrison, S.J.; Clarke, M.F.; Weissman, I.L. Stem cells, cancer, and cancer stem cells. Nature 2001, 414, 105-111. [CrossRef] [PubMed]

239. Al-Hajj, M.; Wicha, M.S.; Benito-Hernandez, A.; Morrison, S.J.; Clarke, M.F. Prospective identification of tumorigenic breast cancer cells. Proc. Natl. Acad. Sci. USA 2003, 100, 3983-3988. [CrossRef] [PubMed]

240. O'Brien, C.A.; Pollett, A.; Gallinger, S.; Dick, J.E. A human colon cancer cell capable of initiating tumour growth in immunodeficient mice. Nature 2007, 445, 106-110. [CrossRef]

241. Singh, S.K.; Hawkins, C.; Clarke, I.D.; Squire, J.A.; Bayani, J.; Hide, T.; Henkelman, R.M.; Cusimano, M.D.; Dirks, P.B. Identification of human brain tumour initiating cells. Nature 2004, 432, 396-401. [CrossRef]

242. Avril, T.; Vauleon, E.; Hamlat, A.; Saikali, S.; Etcheverry, A.; Delmas, C.; Diabira, S.; Mosser, J.; Quillien, V. Human glioblastoma stem-like cells are more sensitive to allogeneic NK and T cell-mediated killing compared with serum-cultured glioblastoma cells. Brain Pathol. 2012, 22, 159-174. [CrossRef]

243. Jachetti, E.; Mazzoleni, S.; Grioni, M.; Ricupito, A.; Brambillasca, C.; Generoso, L.; Calcinotto, A.; Freschi, M.; Mondino, A.; Galli, R.; et al. Prostate cancer stem cells are targets of both innate and adaptive immunity and elicit tumor-specific immune responses. Oncoimmunology 2013, 2, e24520. [CrossRef] [PubMed]

244. Tallerico, R.; Todaro, M.; Di Franco, S.; Maccalli, C.; Garofalo, C.; Sottile, R.; Palmieri, C.; Tirinato, L.; Pangigadde, P.N.; La Rocca, R.; et al. Human NK cells selective targeting of colon cancer-initiating cells: A role for natural cytotoxicity receptors and MHC class I molecules. J. Immunol. 2013, 190, 2381-2390. [CrossRef]

245. Ames, E.; Canter, R.J.; Grossenbacher, S.K.; Mac, S.; Chen, M.; Smith, R.C.; Hagino, T.; Perez-Cunningham, J.; Sckisel, G.D.; Urayama, S.; et al. NK cells preferentially target tumor cells with a cancer stem cell phenotype. J. Immunol. 2015, 195, 4010-4019. [CrossRef] [PubMed] 